\title{
A new piece in the puzzle for the riverine slugs of the Acochlidiidae (Gastropoda: Panpulmonata: Acochlidimorpha) helps tracing steps of their freshwater invasion
}

\author{
Bastian Brenzinger $^{1}$ (D) Matthias Glaubrecht ${ }^{2} \cdot$ Katharina M. Jörger $^{1} \cdot$ Michael Schrödl $^{1,3,4} \cdot$ Timea P. Neusser $^{3}$
}

Received: 10 July 2020 / Accepted: 9 December 2020 / Published online: 24 February 2021

(C) The Author(s) 2021

\begin{abstract}
Gastropods (slugs and snails) are prominent and species-rich faunal elements in marine and terrestrial habitats of the tropics. While several clades of snails inhabit freshwater systems, slugs are extremely rare in freshwater: only the centimeter-sized Acochlidiidae, with currently three genera, contain more than one species and live in the lower reaches of island streams in an area comprising Eastern Indonesia, Fiji, and Palau. Where known, the species of this unique group are specialized predators of other amphidromous snails' egg capsules (Neritidae) and their reproductive biology and adaptations to life in freshwater are complex. Acochlidiidae are thus of special interest for evolutionary biology and ecology. We here describe a new genus of unusually bluish-green acochlidiid to date known only from a single locality on the island of Ambon, Indonesia. Previous molecular data found this charismatic species to link slender Strubellia slugs with broad and flattened Acochlidium and Palliohedyle. We establish Wallacellia siputbiru n. gen. n. sp., the "blue slug" in Bahasa Indonesia, by using scanning electron microscopy of cuticular elements, light microscopy of serial semithin histological sections of the soft body, and 3D reconstruction of all organ systems based on these sections. Special structures of this seemingly rare endemic species include the enlarged kidney and the huge copulatory organ. Our data now clarify that, in the invasion of freshwater habitats in Acochlidiidae, sexual selection (the anterior three-part copulatory organ) preceded ecological selection (posterior flattened habitus with branched or multiplied internal organs).
\end{abstract}

Keywords 3 D reconstruction $\cdot$ Tropical islands $\cdot$ Amphidromy $\cdot$ Hermaphrodite $\cdot$ New species $\cdot$ Indonesia

\section{Introduction}

Freshwater gastropods make up about $5 \%$ of global gastropod diversity (4000-8000 estimated species) but account for onefifth of recorded gastropod extinctions (Strong et al. 2008).

\section{Timea P. Neusser}

neusser@biologie.uni-muenchen.de

Bastian Brenzinger

brenzinger@snsb.de

1 SNSB-Bavarian State Collection of Zoology, Münchhausenstr. 21, 81247 Munich, Germany

2 Center of Natural History (CeNak), Zoological Museum, Universität Hamburg, Martin-Luther-King-Platz 3, 20146 Hamburg, Germany

3 LMU Munich, BioZentrum/Department Biology II, Großhaderner Str. 2, 82152 Planegg- Martinsried, Germany

4 GeoBio-Center LMU, Richard-Wagner-Str. 10, 80333 München, Germany
These animals belong to sometimes highly endemic radiations that live in springs, lakes, and rivers and are highly suitable targets for biogeographic and evolutionary studies (e.g., Glaubrecht 1996, 2010; von Rintelen and Glaubrecht 2005; Köhler and Glaubrecht 2010; Lydeard and Cummings 2019). Some freshwater gastropods live mainly in the lower reaches of tropical island streams, for example, many of the common and widespread snails of the family Neritidae (Haynes 1988; Kano 2009; Abdou et al. 2015; Kano and Fukumori 2019) and Thiaridae (Glaubrecht 2010, 2011; Glaubrecht and Neiber 2019). Such groups are often amphidromous, meaning that they live in freshwater as adults but their larvae are swept into the sea and larval development and dispersal happens in the ocean (McDowall 2007). Another such example of amphidromy is the Acochlidiidae Küthe, 1935, a family containing the world's only radiation of freshwater slugs (besides the presumably closely related yet physically smaller and interstitial, monotypic, Tantulum elegans Rankin, 1979 from the Caribbean, and one species of onchidiid slug Onchidium sp., see Rankin 1979; Neusser and Schrödl 2019). The sister group 
of Acochlidiidae, Pseudunelidae, and most of their other relatives are marine and interstitial, i.e., living in the microscopic interstices of marine sand sediments (Jörger et al. 2014a, 2020; Neusser et al. 2011b). Only recently, deeper-water Bathyhedyle Neusser et al. 2016 and semi- or fully terrestrial Aiteng Swennen \& Buatip, 2009, both slugs with a size of 6-15 mm, were recognized as unusual further members of the worldwide group of Acochlidimorpha (also known as Acochlidia) (Neusser et al. 2011a, 2016; Kano et al. 2015). The aquatic forms are set apart from all other gastropods by their diagnostic, coiled, or uncoiled visceral sac (without a shell) that projects freely from the headfoot.

Freshwater acochlidians of the Acochlidiidae have been known before their interstitial counterparts (Strubell 1892; Bergh 1895). They are an Indo-Pacific endemic radiation of characteristic centimeter-sized slugs, consisting of posteriorly flattened Acochlidium Strubell, 1892 and slender Strubellia Odhner, 1937. Acochlidium species have a greenish and leafshaped visceral sac with dorsal spots and subepidermal vessels (e.g., Strubell 1892; Jörger et al. 2014b). The genus is found in Indonesia (A. amboinense Strubell, 1892: Ambon; A. weberi Bergh, 1895: Flores; A. sutteri Wawra, 1979: Sumba), Palau (A. bayerfehlmanni Wawra, 1980: Babelthuap Island), Fiji (A. fijiensis Haynes \& Kenchington, 1991: Vanua Levu; Haase and Wawra 1996), Papua New Guinea, and the Solomon Islands (possible undescribed species; own data). Acochlidium weberi and A. sutteri are sometimes classified in Palliohedyle Rankin, 1979, a poorly known genus that contains large animals with curled visceral sac margins. Palliohedyle was found to be sister of Acochlidium by Jörger et al. (2014b). Species of the genus Strubellia have a reddish-brown, elongate, smooth, and tubular visceral sac and are known from Indonesia ( $S$. paradoxa Strubell, 1985: Ambon, Küthe 1935, Brenzinger et al. 2011a; undescribed species in Brenzinger et al. 2011b, Sulawesi), Vanuatu and Solomon Islands ( $S$. wawrai Brenzinger et al. 2011b; Wawra 1974, 1988), and the Bismarck Archipelago (P. Bouchet pers. comm.). Relationships of many of these species were examined by Jörger et al. (2014b) but species status of some, in particular A. bayerfehlmanni and A. sutteri, remains to be confirmed. All acochlidiids appear to be amphidromous, live in streams of tropical islands, and prey upon the egg capsules of Neritidae (Brenzinger et al. 2011b; Jörger et al. 2014b).

During a survey of freshwater gastropods on Ambon, eastern Indonesia, a single pair of freshwater acochlidians was collected that had an unusual blue-green color and did not fit with any of the known species or genera: The animals had a slender body like Strubellia but their coloration and pattern resembled more that of Acochlidium. Molecular phylogenetic study (Jörger et al. 2014b) showed this animal to be sister to the clade of brownish and greenish patterned Acochlidium and Palliohedyle, together forming the sister group to uniformly reddish-brown Strubellia. A later study with differing taxon sampling found the animal to be sister to only Palliohedyle (Neusser et al. 2016: Fig. 1), however, with poor statistical support. Anatomical study (SEM, histology, 3D reconstruction) found several intermediate morphological characters in line with a phylogenetic position linking Acochlidium/Palliohedyle on the one hand and Strubellia on the other. Based on these data, we herein describe a new genus and species to accommodate this blue-green acochlidiid from Ambon Island, Indonesia.

\section{Material and methods}

\section{Sampling and preservation}

Living gastropods were collected during a field survey of the freshwater gastropods of Amboina (Ambon Island) and Maluku Utara (Moluccas Province), Indonesia, during late October 2008. Specimens were collected by hand from the sediment of small streams or by turning rocks. Several acochlidiids were found in a stream on the southeast coast of Ambon Island (eastern part of Leihitu), in a stream under the road from Passo to Natsepa just west of Waitatiri, on 21 October 2008. This included two individuals of Wallacellia siputbiru n. gen. n. sp. found on the underside of the same stone in roughly $20 \mathrm{~cm}$ deep, slightly turbid water, about $120 \mathrm{~m}$ from the river's mouth $\left(3^{\circ} 37.052^{\prime} \mathrm{S}, 128^{\circ}\right.$ $\left.16.262^{\prime} \mathrm{E}\right)$. The living animals were later observed in a glass container and then preserved in $75 \%$ ethanol. Other acochlidiid slugs living in the same stream were Acochlidium amboinense (2 specimens, Museum für Naturkunde Berlin, Germany, voucher number ZMB Moll 193942) and Strubellia paradoxa (1 specimen, ZMB Moll 193944).

\section{Preparation of vouchers}

The anterior part of the holotype (Museum Zoologi Bogor, Indonesia, voucher number MZB Gast.21.774) was macerated in $10 \% \mathrm{KOH}$. Spicules, the radula, and chitinous hard parts of the copulatory organ were removed from the solution, cleaned with minute needles, and rinsed several times with double distilled water under a microscope, where they were also photographed in transmitted light. The cleaned samples were transferred onto SEM stubs with double-sided carbon tabs and air dried; afterwards the stubs were coated with gold for $120 \mathrm{~s}$ (SEM-Coating-System, Polaron, Watford, UK) and the structures imaged using a LEO $1430 \mathrm{VP}$ scanning electron microscope (SEM). The posterior part of the holotype was used for full genomic DNA extraction, sequencing, and phylogenetic analysis (see Jörger et al. 2014b for details).

The paratype specimen (ZMB Moll 193966) was decalcified in $1 \%$ ascorbic acid overnight, dehydrated in a graded series of acetone solutions (70 to $100 \%$ ), and embedded in Epon epoxy resin (REF; block number 4S4). Serial semithin sections (thickness $1.5 \mu \mathrm{m}$ ) were prepared using a diamond knife (Histo Jumbo, Diatome, Biel, Switzerland) 
Fig. 1 Type locality and living specimens of Wallacellia siputbiru n. gen. n. sp. and 3D reconstruction of complete paratype. A Map of Ambon Island with type locality (red dot) $\mathbf{A}^{\prime}$ Location of Ambon within Indonesia (insert). B Photograph of type locality (about $300 \mathrm{~m}$ upstream from collecting site). $\mathbf{C}$, $\mathrm{C}^{\prime}, \mathrm{C}^{\prime \prime}$ Living specimens crawling on the wall of a glass of water. $\mathrm{C}$ Dorsal view, asterisk indicates position of mantle "hood." $\mathrm{C}^{\prime}, \mathrm{C}^{\prime}$ Ventral views, note enlarged right rhinophore. D Preserved paratype embedded in Epon epoxy resin (left view). Note blue-green coloration. E 3D-reconstructed paratype, anterior right view, showing enlarged right rhinopore and copulatory organ. F Paratype, right view, overview of organ systems, body outline shown transparent. Abbreviations: cop, copulatory organ; dg, digestive gland; ey, eye; ft., foot; go, gonad; hf, headfoot; kd, kidney; lt (right), labial tentacle; nd, nephroduct; pc, pericardium; rh (right), rhinophore; vs, visceral sac. Scale bars: $\mathbf{F} 5 \mathrm{~km}, \mathrm{~A}^{\prime} 500 \mathrm{~km}, \mathbf{E}$ $500 \mu \mathrm{m}, \mathbf{F} 1 \mathrm{~mm}$. Map data: Creative Commons, Esri, NASA, NGA, USGS/Esri, HERE, Garmin, METI/NASA, USGS

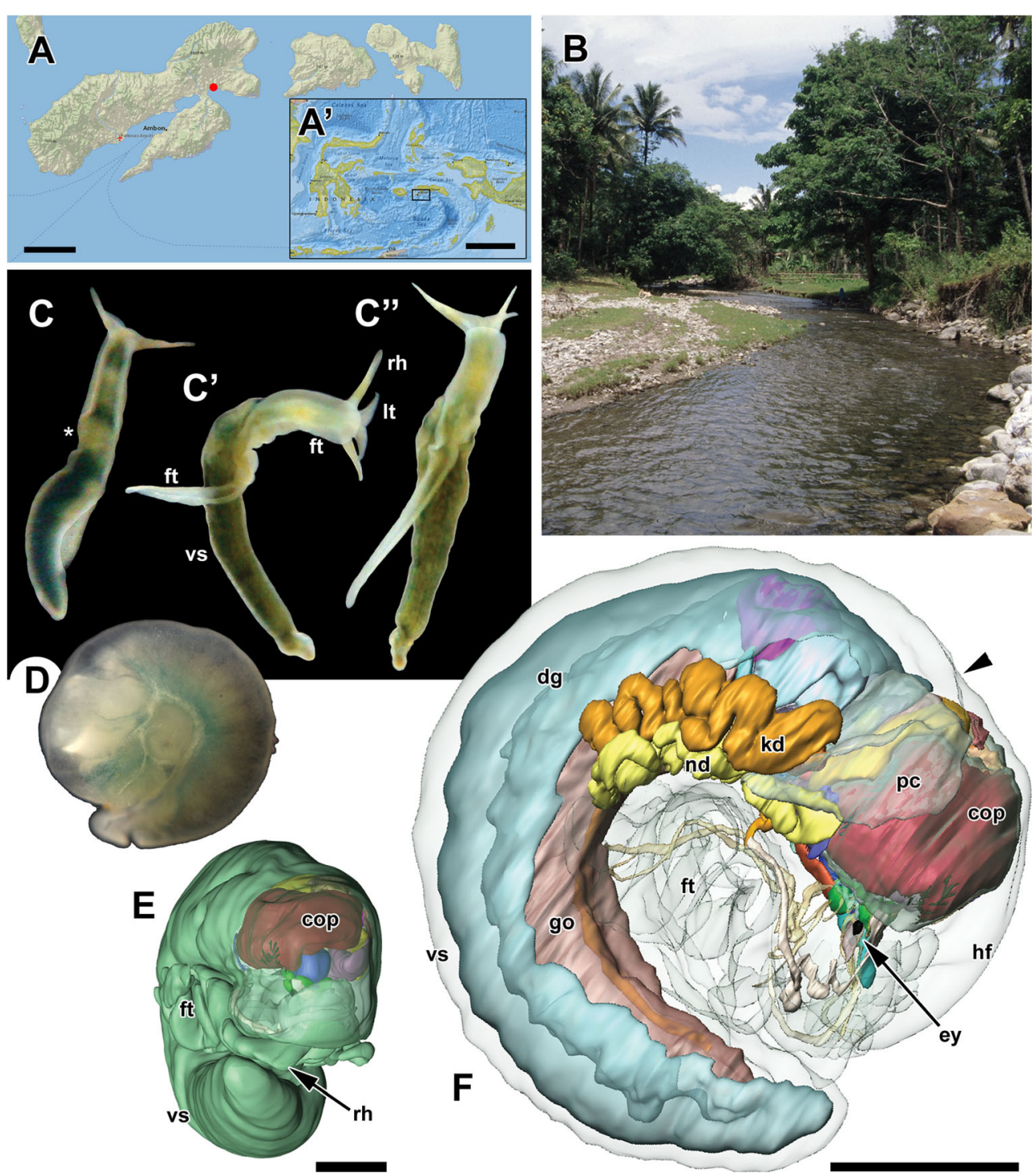

following the protocol described in Ruthensteiner (2008); sections were stained with methylene blue-azure II according to Richardson et al. (1960). Digital images of the entire series were taken with a ProgRes SpeedXT Core 5 camera (Jenoptik Optical Systems, Jena) mounted to a Leica DM5000B microscope (Leica Microsystems, Germany). A set of 1072 images showing the entire animal was converted to gray scale, downscaled to $1024 \times 759$ pixels resolution using Photoshop and imported into Amira 5.3 software (Visage Imaging, Berlin, now Thermo Fisher Scientific) for alignment and 3D reconstruction. The outlines of the body and all major organ system were labeled by hand and interpolation tools; 3D surfaces were reconstructed and rendered based on these labels. Additional higher-resolution image stacks for detailed examination of the CNS and the copulatory organ were created in the same way.

Figures were compiled using digital images, screenshots of rendered 3D models, high-resolution histological images taken with a dotSlide Olympus VS-ASW (FL) (Olympus Scientific Solutions Americas Corporation), and drawings created using Inkscape (Free Software Foundation, Inc.).

Nomenclatural acts and the published work itself were registered as LSIDs (Life Science Identifiers) in ZooBank, the online registration system associated with the International Code of Zoological Nomenclature (ICZN). These records can be accessed via web browsers by adding the LSID to the prefix "http://zoobank.org/". The LSID for this publication is urn:1sid:zoobank.org:pub:D9135C96-9E67-4B46-B79C93DA3230856D.

\section{Results-species description}

The classification here is based on molecular data (Jörger et al. 2014b), the system proposed by Bouchet et al. (2017) and the morphological analyses presented herein. 


\section{Systematics}

Subclass Heterobranchia sensu Haszprunar, 1985

Subcohort Panpulmonata Jörger et al., 2010

Superorder Acochlidimorpha sensu Bouchet et al., 2017 (Acochlidia sensu Wawra, 1987)

Superfamily Acochlidioidea Küthe, 1935 (Hedylopsacea sensu Wawra, 1987)

Family Acochlidiidae Küthe, 1935

New genus Wallacellia

Z o o B a n k regi st ration (L S I D ) : urn:1sid:zoobank.org:act:1E77A184-3CF1-425C-BBB5A68F16A4E788

Etymology: Genus named in honor of the British naturalist Alfred Russel Wallace (1823-1913), one of the pioneers of evolutionary theory and biogeography. He described the natural history of Indonesian islands in this two-volume "The Malay Archipelago," including the Moluccas and the island of Ambon (Wallace 1869). Ending "-ellia" also alluding to the externally similar genus Strubellia.

Diagnosis: See species diagnosis below.

Type species: Wallacellia siputbiru new species, here designated, type by monotypy

\section{Wallacellia siputbiru new species}

Synonyms: "Acochlidiidae MOTU Ambon CIP 12": Jörger et al. 2014b. "Acochlidiidae MOTU Ambon": Neusser et al. 2016

ZooBank registration (LSID): urn:lsid:zoobank.org:act: 02948608-15A0-4 AD6-B392-622BAF4943A7.

Type material: Holotype (MZB Gast.21.774), isolated radula, and copulatory cuticle elements mounted on SEM stub, gold coated. 1 paratype (ZMB Moll 193966), series of semithin histological sections (35 slides), serially sectioned, stained with Richardson's stain, sealed with araldite resin, digitized, and 3D reconstructed. No further specimens known to date

Type locality: Small estuary of unknown name, west of Waitatiri, northwestern part of Baguala Bay, southeastern coast of Ambon (Amboina) island, Maluku Utara Province (Moluccas archipelago), Indonesia

Etymology: The species epithet refers to the unusual (for an acochlidian) bluish-emerald-green coloration of living specimens, "siput" meaning "slug" and "biru," "bluish" in Bahasa Indonesia, the official language spoken on Amboina.

Diagnosis: With characters of genus (see Table 1); bluishgreen freshwater acochlidiid slugs of 8-10-mm adult size, with yellowish foot and tentacles, and possibly with faint dark "mask"-like pigmented pattern on headfoot. With two pairs of tapering head tentacles, rhinophores longer than the labial tentacles, right rhinophore (temporarily?) enlarged. Anterior foot corners rounded and not projecting, posterior foot tapering and free. Visceral sac slender, freely projecting beyond foot, slightly flattened in cross section. Asymmetric radula (formula $40 \times 2.1 .1$ ), rhachidian tooth with narrow median denticle and minute serrations along margin, lateral plates flat and rectangular and with denticle and matching notch, small diamond-shaped second lateral plate on left side. Large sacshaped kidney with proximal and distal lumina, strong muscular heart with thick epicardial layer, single renopericardioduct. Hermaphroditic reproductive tract with sac-like ampulla, receptaculum seminis integrated intro albumen gland, small bursa copulatrix, and closed vas deferens. Large, three-part copulatory organ armed with 5 different cuticular structures: penis (with comb, long retractable stylet, and basal muscular bulb, connected to prostate), basal finger (with stout stylet connected to paraprostate), grappling organ (with two rows of each 14 apical thorns and one basal field with 24 spines)

\section{General morphology}

Living specimens of Wallacellia siputbiru $\mathrm{n}$. gen. n. sp. are slender slugs of 8-10 mm length (Fig. 1C-C"). The headfoot bears two pairs of tapering cephalic tentacles: the anteroventral labial tentacles are curved and fused in the middle forming an upper lip above the mouth (Fig. 1C'); the more posterodorsal rhinophores are cylindrical, straight, and longer than the labial tentacles. The right rhinophore was longer than the left one in both examined specimens and had a thicker base (Fig. 1C', C', E). In dorsal view, the headfoot behind the tentacles is first cylindrical and then widens into a wider, bulbous, and apparently spacious area ("mantle hood") before joining to the visceral sac (asterisk and pale area in middle of Fig. 1C). The ventral foot sole is rounded anteriorly, is wider than the headfoot, and extends freely underneath the visceral sac, ending in a narrow tip. The visceral sac extends freely beyond the posterior bulb of the headfoot and is as long as the headfoot or about $50 \%$ longer. It is rounded or somewhat flattened and ventrally concave (Fig. 1 $\mathrm{C}^{\prime \prime}$ ). In crawling specimens, the visceral sac is quite flexible in position and length, hanging downwards in specimens crawling on a vertical glass surface (Fig. 1C'). Headfoot and visceral sac are colored emerald to dark bluish-green, and the head tentacles and foot are yellowish green. Seen from above, the area around the pharynx, the mantle hood, and the anterior right side of the visceral sac (position of the kidney) is also paler yellow-green, and there is a pale transversal band in the middle of the headfoot. The blue-green coloration persisted in ethanol-preserved and epoxy resinembedded specimens.

Preserved specimens retract the posterior half of the headfoot into the space inside the mantle hood and contract the visceral sac into a half-circle that curves ventrally underneath the head, with the foot remaining free inside the middle, giving the slug a disk-like shape (Fig. 1D, E, F).

Internally, the headfoot and the visceral sac are divided by a transversal muscular diaphragm at the posterior end of the mantle hood (arrowhead in Fig. 1F). A second, longitudinal, 
Table 1 Morphological comparison of freshwater Acochlidiidae and marine interstitial Pseudunelidae (sister group within Acochlidimorpha)

Pseudunelidae (outgroup) Strubellia Wallacellia siputbiru n. gen. n. Acochlidium/Palliohedyle sp.

\begin{tabular}{|c|c|c|c|c|}
\hline Habitat & Marine interstitial & Freshwater, benthic & Freshwater, benthic & Freshwater, benthic \\
\hline Size & $1-4 \mathrm{~mm}$ & $6-40 \mathrm{~mm}$ & $8-10 \mathrm{~mm}$ & $6-30 \mathrm{~mm}$ \\
\hline Anterior corners of foot & Rounded & $\overline{\text { Projecting (slightly flaring) }}$ & $\overline{\text { Rounded }}$ & $\overline{\text { Projecting (pointy) }}$ \\
\hline Coloration & Colorless (white) & $\begin{array}{l}\text { Colored (Uniform } \\
\text { orange-red) }\end{array}$ & Colored (blue-green) & $\begin{array}{l}\frac{\text { Colored (orange-brown to }}{\text { green, some white spots) }} \\
\text { s. }\end{array}$ \\
\hline Pigment patterns on head & None & None & Faint? & $\begin{array}{l}\text { Black, sharply demarcated } \\
\text { 'mask' }\end{array}$ \\
\hline Rhachidian tooth & 3-7 denticles per side & $30+$ denticles/side & $\underline{30+\text { denticles/side }}$ & $\frac{30+\text { denticles/side, }}{\text { (Palliohedyle: } 7-9)}$ \\
\hline $\begin{array}{l}\text { Cross section of visceral } \\
\text { sac }\end{array}$ & Round & Round & Slightly flattened & $\begin{array}{l}\text { Very flat, crenulated at } \\
\text { margins (Palliohedyle) }\end{array}$ \\
\hline Gonad and digestive gland & Tubular & Tubular & Tubular & Branched \\
\hline $\begin{array}{l}\text { Kidney, } \\
\text { renopericardioducts } \\
\text { (rpd) }\end{array}$ & Sac-like or tubular/one rpd & Tubular/one rpd & Tubular/one rpd & $\frac{\text { Tubular/multiple rpd's/dorsal }}{\text { vessels* }}$ \\
\hline Bursa and vas deferens & $\begin{array}{l}\text { Present or missing/closed } \\
\text { duct }\end{array}$ & Present/open groove & $\begin{array}{l}\text { Present (but small?)/closed } \\
\text { duct? }\end{array}$ & No bursa/closed duct* \\
\hline $\begin{array}{l}\text { Ampulla and } \\
\text { receptaculum } \\
\text { seminis }\end{array}$ & Sac/sac, or missing & Tube/sac & $\mathrm{Sac} / \mathrm{sac}$ & Tube/missing?* \\
\hline Penial stylet & $\begin{array}{l}\text { Long and apical } \\
\quad(70-600 \mu \mathrm{m}) \\
\quad \text { or missing (detachable?) }\end{array}$ & Missing & Long $(1600 \mu \mathbf{m})$ but retractable & $\begin{array}{l}\text { Long ( } 500 \mu \mathrm{m} \text { but possibly } \\
\text { much longer) but retractable* }\end{array}$ \\
\hline Penial apical cuticle & Not present & Present (Hook) & Present (Comb) & Present (Hook-like "thorn")* \\
\hline Bulb underlying penis & Not present & Not present & Present, large & Not present, or small?* \\
\hline Basal finger stylet & $\begin{array}{l}\text { Present, long or short, tube } \\
\quad(30-300 \mu \mathrm{m})\end{array}$ & $\begin{array}{l}\text { Long, enrolled } \\
\quad(500-1000 \mu \mathrm{m})\end{array}$ & Short, tube $(200 \mu m)$ & Short, tube $(50-100 \mu \mathrm{m})^{*}$ \\
\hline $\begin{array}{l}\text { Grappling organ (apical } \\
\text { thorns/basal spines) }\end{array}$ & Not present & Not present & $\begin{array}{l}\text { Present, with } 14+14 \\
\text { thorns, } 24 \text { spines }\end{array}$ & $\begin{array}{l}\text { Present, with 8-9+8-9 } \\
\text { thorns, 8-10 spines (or } \\
\text { none?) (Palliohedyle: } 14 \\
\text { thorns and } 30 \text { spines?) }\end{array}$ \\
\hline
\end{tabular}

Selected data compiled from the present study and literature. Sources, Pseudunelidae: Neusser and Schrödl (2009), Neusser et al. (2011b). Strubellia: Brenzinger et al. (2011b). Acochlidium/Palliohedyle: Bergh (1895), Haase and Wawra (1996), Schrödl and Neusser (2010) and own observations

Underlined script indicates presumed synapomorphies of all Acochlidiidae, or the clade of Wallacellia n. gen. n. sp. and Acochlidium/Palliohedyle. Bold script indicates presumed autapomorphies for each genus. Italic script indicates "intermediate" characters of Wallacellia. Question marks indicate presently unclear characters that need further investigation. Asterisk: no data on Palliohedyle

muscular sheet encloses most of the internal organs: the eyes, central nervous system, anterior digestive tract including half the esophagus, and the huge copulatory organ enclosed in the penial sheath lie in the anterior body cavity; the digestive gland and gonad occupy most of the posterior cavity inside the visceral sac. The circulatory and excretory systems, save the aorta, are located in the anterior right of the visceral sac and lie outside the aforementioned longitudinal muscle sheet (Fig. 2A, stippled line in Fig. 6). It appears that all muscles or muscle fibers adhering to internal organs pass through these two muscle sheets and anchor them to the musculature of the foot that in turn attaches to the foot sole. Mucus glands, identifiable by their pale or dark purple stain, are located in most of the epidermis and, subepithelially, in the entire foot (Fig. 2A). Subepithelial connective tissue with embedded calcareous spicules is found inside the tentacles, foot, and sides of the headfoot and visceral sac and forms a thick layer around the central body cavity which contains the organs (asterisk in Fig.
2A). The monaxone (unbranched) spicules are $60-150-\mu \mathrm{m}$ long and slightly curved and have rounded ends.

\section{Digestive tract}

The mouth of Wallacellia siputbiru n. gen. n. sp. is a vertical slit between the labial tentacles. The following oral tube is short and muscular, surrounded ventrally by dark purplestaining subepithelial glands (oral glands?). The pharynx is a drop-shaped muscular mass (Fig. 2A) that surrounds the cuticularized pharyngeal cavity. The anterior part of the pharyngeal cavity bears thick cuticle that forms two lateral, liplike pads and in the middle contains the exposed, folded open functional part of the radula (Fig. 2D). The radula is hookshaped, with an upper limb that is about $600-\mu \mathrm{m}$ long and a lower limb that is $250-\mu \mathrm{m}$ long. Both histological sections and SEM imaging show that the radula itself consists of about 40 tightly interlocked series of cuticular teeth attached to the 
radular membrane (Figs. 2C,D and 4). Each row consists of an erect, slender triangular rhachidian tooth in the middle $(60 \mu \mathrm{m}$ tall $\times 40 \mu \mathrm{m}$ wide) that has a robust, angular base and a slender, finely serrated upper region (the functional part of the tooth) (Fig. 4A, B). This erect part is eroded down to its base in most of the anterior-pointing rhachidians and in all of those of the ventral limb of the radula (Figs. 2C, D and 4A, C), but it is complete in most of the upper limb. On the left side of each rhachidian tooth lies a subrectangular, flat plate (left lateral plate, $45 \times 20 \mu \mathrm{m}$ ) with rounded corners, a triangular denticle on the proximal margin (= posterior/towards the origin of the radula) and a correspondingly shaped notch on the distal-facing (anterior) margin (Fig. 4A, C). On the right side of each rhachidian tooth lies a similarly shaped plate with notch and corresponding denticle; the right lateral plate however is less wide but has a straight outer margin that is immediately adjacent to a small, rhomboid second lateral plate making the radula asymmetric (radula formula $40 \times 2.1 .1$ ) (Fig. 4A). In situ, this second right lateral plate is folded underneath the first right lateral plate (Fig. 2C). About $100 \mu \mathrm{m}$ of the upper and the entire lower limb of the radula lie folded open in the pharyngeal cavity. In situ, the upper limb dives posteriorly into the musculature of the pharynx where the still folded radula and its teeth are formed. There, the pharyngeal cavity is dorsal, less cuticularized, and triangular; the dorsal side forms a ciliated gutter leading to the esophagus while the lateral parts bear the paired openings of the salivary ducts. The salivary ducts are about 500- $\mu \mathrm{m}$-long epithelial, muscular yet unciliated, tubes that each have a median bulbous reservoir and distally project into the central lumen of the large and paired salivary glands (Fig. 3A). The salivary glands stain deeply purple-blue (Fig. 2E); in the retracted specimen, the right salivary lies on top of the pharynx while the left one is shifted to the posterior right of it. The esophagus emerges from the posterodorsal side of the pharyngeal bulb and is a straight tube traversing the muscular diaphragm into the body cavity of the visceral sac. The lumen of the esophagus is circular, with strongly ciliated epithelium, and surrounded by a thick coat of smooth longitudinal muscle fibers (Fig. $2 \mathrm{E})$ that originate from the back of the pharynx and later extend into the ventral part of the longitudinal muscle sheet surrounding the internal organs. The posterior end of the esophagus curves dorsally into the digestive gland, about $300 \mu \mathrm{m}$ left to where the intestine later originates (Fig. 1A). The esophagus opens into the digestive gland without passing a detectable stomach. The digestive gland is a simple sac that extends anterodorsally until the muscular diaphragm and posterodorsally until the tip of the visceral sac; in the reconstructed animal, it is for the most part pushed to the periphery, forming a roughly 200 - $\mu \mathrm{m}$-thick layer that surrounds the enlarged ovotestis (Fig. 2A). The epithelium of the digestive gland consists mainly of tall columnar cells that stain blue and contain numerous spherical unstained vesicles. The intestine is a thin and straight, ciliated tube emerging from the anterior right of the digestive gland and traverses the body musculature before opening into a barely discernible anus that lies in a constricted and retracted epidermal pocket below the right anterior end of the visceral sac. The nephropore lies in the same pocket, the genital opening about $400 \mu \mathrm{m}$ more anterior (see below).

\section{Central nervous system}

The core ganglia of Wallacellia siputbiru $n$. gen. $n$. sp. lie in a circle around the anterior part of the pharynx (Fig. 3A). Paired cerebral, pleural, and pedal ganglia lie anteriorly (forming the cerebral nerve ring); unpaired left parietal, fused subintestinal/ visceral, fused supraintestinal/right parietal, and osphradial ganglia lie directly behind in a u-shape below the anterior pharynx (constituting the ganglia of the visceral loop, with the osphradial ganglion forming an extension of it to the right); paired buccal ganglia lie below the posterior tip of the pharynx (forming the buccal loop) (Figs. 3B, 5). The ganglia of the cerebral nerve ring are joined on the left and right sides by three short connectives and interconnected from left to right by the longer cerebral and pedal commissures above and respectively below the pharynx. The ganglia of the visceral loop are arranged on a long nerve cord interconnecting the left and right pleural ganglia; the connectives are short but the stretch between the fused subintestinal/visceral ganglion on the left side and the fused supraintestinal/right parietal ganglion on the right side is about $300-\mu \mathrm{m}$ long and passes beneath the middle of the pharynx. The buccal ganglia are linked by a short commissure and connect to the cerebral ganglia by long cerebro-buccal connectives running though the pharynx musculature. Further minute ganglia are the paired rhinophoral and optic ganglia (two on the outer side of each cerebral ganglion) and the paired gastroesophageal ganglia (joined to each buccal ganglion by a short connective). Sensory organs are the paired, bean-shaped eyes (adjacent to the optic ganglia, with pigment cup and vitreous body facing anterolaterally; Fig. 2B) and the paired, spherical statocysts (on top of each pedal ganglion; with single statolith; Fig. 3); paired Hancock's organs or an unpaired osphradium (present in other acochlidians) was not detected but could have been hidden in folds of the retracted body. An irregularly shaped mass of cells, resembling connective tissue but with darker nuclei, adheres to the top of the cerebral commissure and parts of the left cerebral ganglion (cgl in Fig. 3B, B'). Ganglia are all surrounded by a light blue staining sheet of connective tissue and contain darker-stained neuron somata and grayish-stained irregularly shaped medullary mass containing the nerve fibers (Fig. 2B).

Nerves connecting the ganglia to the periphery have the same histology as medullary mass, connectives, and commissures. Paired nerves of the cerebral nerve ring are (Fig. 5) (1) the 

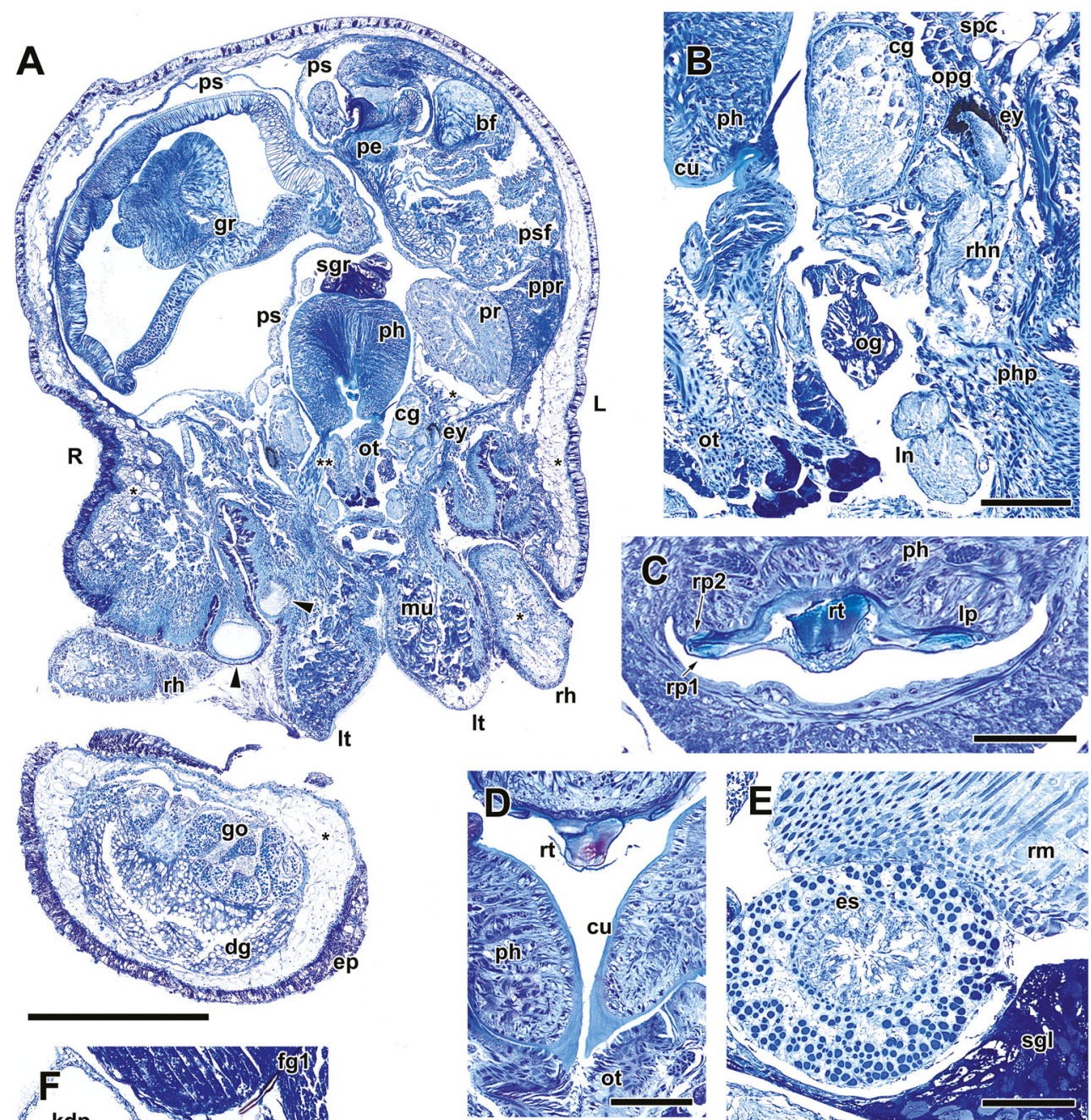
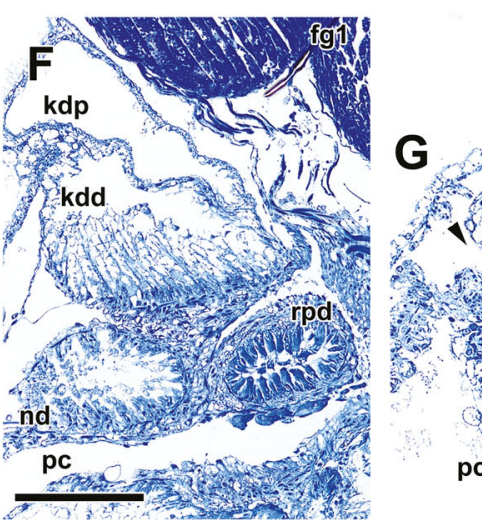

Fig. 2 Semithin histological sections of Wallacellia siputbiru n. gen. $\mathrm{n}$. sp. paratype showing aspects of digestive, central nervous, excretory, and circulatory systems. All cross sections, anterior view, dorsal side up. A Complete headfoot and visceral sac (slice 225). Asterisks indicate connective tissue containing spicules, double asterisk indicates (right) pharyngeal protractor muscle, two arrowheads highlight inflated posterior-leading vas deferens containing spermatozoa. B Detail of A showing area around left cerebral ganglion (slice 225). C Detail of folded open radula in descending limb (slice 294). D Detail of radula near anterior cuticle (slice 252). E Detail of anterior esophagus (slice 439). F Renopericardioduct and kidney (slice 492). G Heart (slice 439). H Detail of A showing inflated posterior-leading vas deferens, arrowhead highlights spermatozoa (slice 225). Abbreviations: R, right side; L, left side; au, auricle; bf, basal finger; bvd, posterior-leading vas deferens; cg,
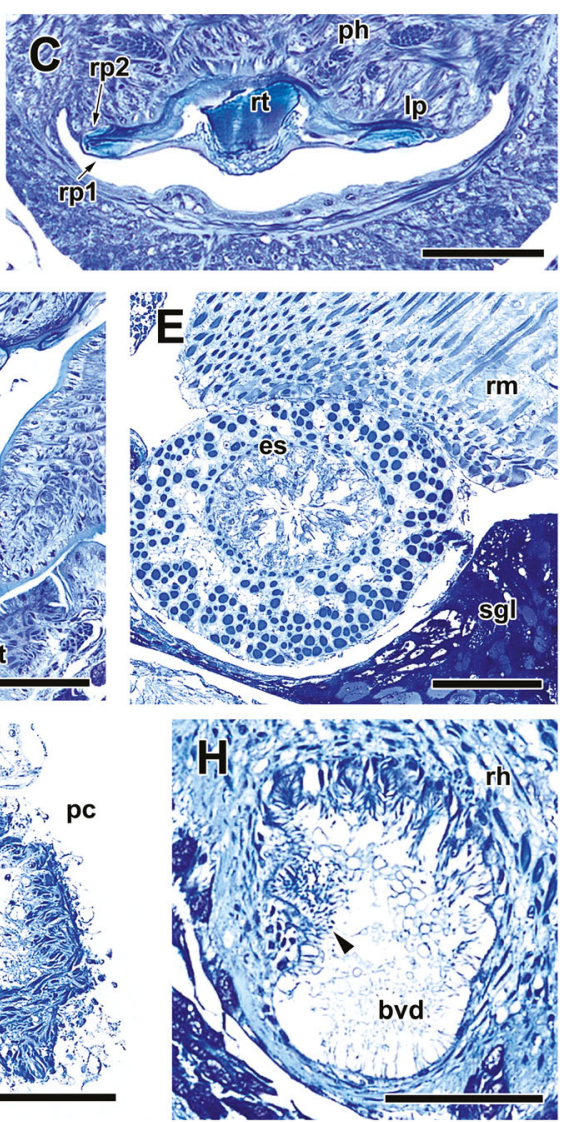

cerebral ganglion; cu, cuticle; dg, digestive gland; ep, epidermis; es, esophagus; ey, eye; fg1, proximal female/nidamental gland; go, gonad (ovotestis); gr, grappling organ; kdd, distal lumen of kidney; kdp, proximal lumen of kidney; ln, labiotentacular nerve; lp, left lateral plate; lt, labial tentacle; mu, mucus glands; nd, nephroduct; og, oral gland; opg, optic ganglion; ot, oral tube; pc, lumen of pericardium; ph, pharynx musculature; php, pharynx protractor; pr, prostate; ps, penial sheath; ppr, paraprostate; psf, folded area of penial sheath; rh, rhinophores; rhn, rhinophoral nerve; rm, retractor muscle of copulatory organ; rt, rhachidian tooth; $\mathrm{rp} 1$, first right lateral plate; $\mathrm{rp} 2$, second right lateral plate; rpd, renopericardioduct; sgl (left), salivary gland; sgr (right), salivary gland; spc, spicules; ve, ventricle. Scale bars: (A) $500 \mu \mathrm{m} ;(\mathbf{B}, \mathbf{F}, \mathbf{G})$ $100 \mu \mathrm{m} ;(\mathbf{C}, \mathbf{D}, \mathbf{E}, \mathbf{H}) 50 \mu \mathrm{m}$ 


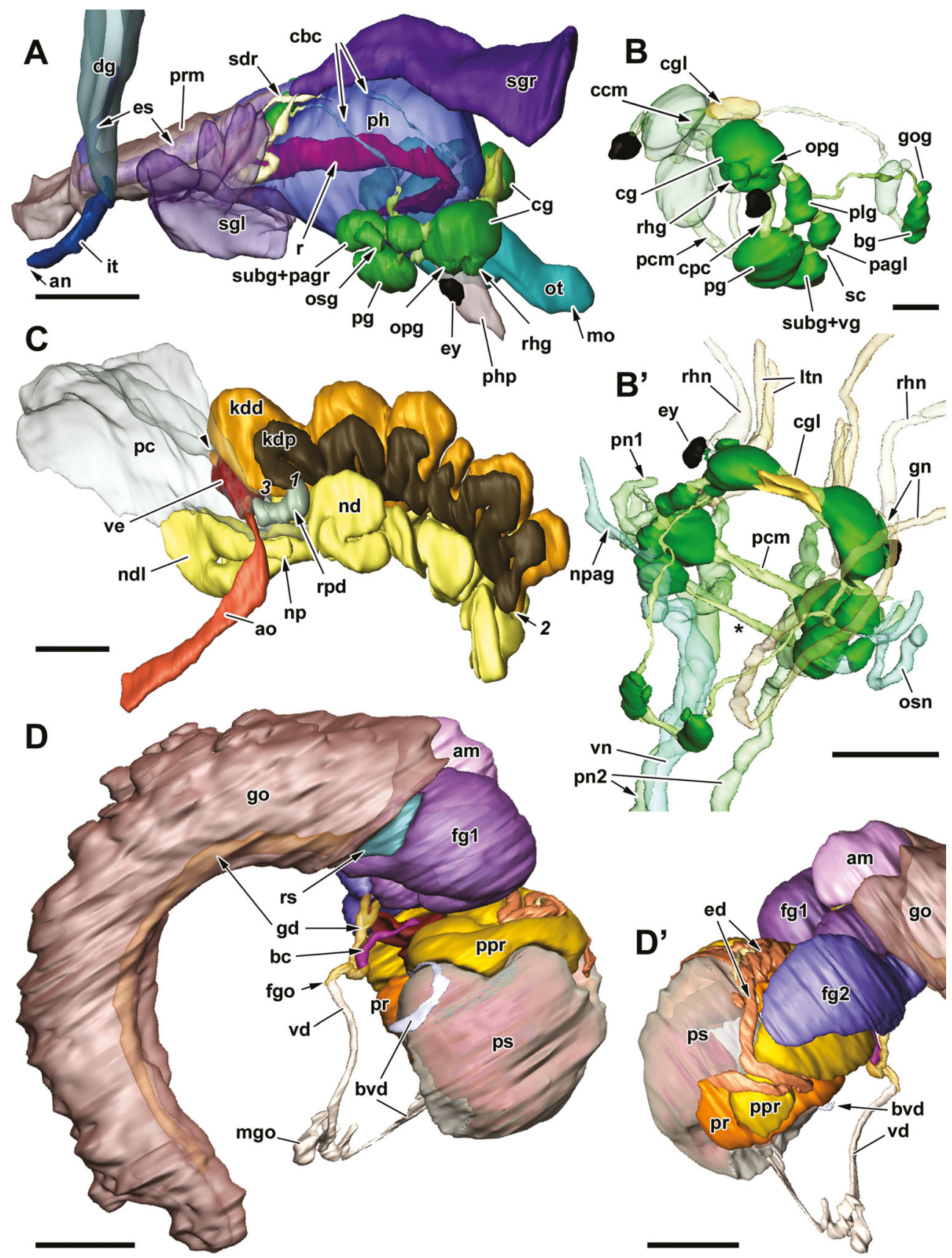

Fig. 3 3D reconstructions of Wallacellia siputbiru n. sp. internal organ systems (paratype). A Anterior digestive tract and nerve ring (right view). B Ganglia of the central nervous system (CNS) (left view, structures of right side shown transparent). B' Nerves of the CNS (dorsal view), asterisk indicates long connective of visceral loop. C Excretory and circulatory systems (left view). Asterisk indicates opening of auricle to hemocoel: (1) position of connection of renopericardioduct to proximal kidney lumen, (2) position of pore between proximal and distal kidney lumina, (3) position of pore between distal kidney lumen and nephroduct. D Reproductive system (right view). D' Reproductive system, anterior part (left view). Abbreviations: am, ampulla; an, anus; ao, aorta; bc, bursa copulatrix; bvd, posterior-leading part of vas deferens; cbc, cerebro-buccal connective; $\mathrm{ccm}$, cerebral commissure; cg, cerebral ganglion; cgl, "cerebral gland"; cpc, cerebro-pedal connective; dg, anterior tip of digestive gland; ed, ejaculatory duct; es, esophagus; ey, eye; fg1, proximal female/nidamental gland; fg2, distal female/nidamental gland; fgo, female gonopore; gd, gonoduct; go, gonad; gn, nerve of the penial sheath; it, intestine; kdd, distal lumen of the kidney; kdp, proximal lumen of the kidney; ltn, labial tentacle nerve; mgo, male gonopore; mo, mouth opening; nd, nephroduct; ndl, loop of nephroduct; np, nephroporus; npag, parietal nerve; opg, optic ganglion; osg, osphradial ganglion; osn, osphradial nerve; ot, oral tube; pagl, left parietal ganglion; pagr, right parietal ganglion; pc, pericardium; pcm, pedal commissure; pg, pedal ganglion; ph, pharynx; php, pharynx protractor muscle; pn1, lateral pedal nerve; pn2, posterior pedal nerve; ppr, paraprostate; pr, prostate; prm, muscle surrounding esophagus; ps, penial sheath; r, radula; rhg, rhinophoral ganglion; rpd, renopericardioduct; rhn, rhinophoral nerve; rs, receptaculum seminis; sc, statocyst; sdr, right salivary duct with reservoirs; sgl, left salivary gland; sgr, right salivary gland; subg, subintestinal ganglion; vd, vas deferens; ve, ventricle; vg, visceral ganglion; vn, visceral nerve. Scale bars: $\left(\mathbf{A}, \mathrm{B}^{\prime}, \mathbf{C}\right) 250 \mu \mathrm{m},(\mathbf{B}) 100 \mu \mathrm{m},\left(\mathbf{D}, \mathrm{D}^{\prime}\right)$ $500 \mu \mathrm{m}$ 
thick rhinophoral nerves connecting the cerebral ganglia via the rhinophoral ganglia to the tip of the rhinophores, (2) the thick and early bifurcating labiotentacular nerves between the cerebral ganglia and the upper lip and labial tentacles, (3) the thin optic nerves presumably connecting the optic ganglion to the posterior end of the eyes, (4-6) the thin nerves connecting the sides of the pedal ganglia to the anterior and lateral sides of the foot sole (pn1, pn3, and pn4 in Fig. 5), and (7) the thick pedal nerves emerging from the anterior sides of the pedal ganglia and running posteriorly along the middle of the foot (pn2 in Fig. 5). Unpaired nerves of the cerebral nerve ring are (8) a putative oral nerve emerging from the right cerebral ganglion and running towards the mouth and (9) a very thick presumed genital nerve emerging also from the right cerebral ganglion and looping posterodorsally, first along the ventral side of the penial sheath and then towards the posterior-leading part of the vas deferens. Unpaired nerves of the visceral and buccal loops are (1) the two nerves emerging from the left parietal and the fused supraintestinal/right parietal ganglia and running towards the sides of the headfoot; (2) the very thick visceral nerve emerging from the fused subintestinal/visceral ganglion and running into the visceral sac where it presumably innervates several organs; (3) one nerve running anteriorly from the osphradial ganglion; (4) a second, thicker nerve running posteriorly from the osphradial ganglion (the osphradial nerve?); and finally (5) a thin nerve emerging medially from the buccal commissure and presumably innervating the radula. Other, particularly, fine nerves or branches thereof may be present but could have escaped our attention.

\section{Circulatory and excretory systems}

The main parts of these systems lie in the anterior right part of the visceral sac of Wallacellia siputbiru n. gen. n. sp. They lie between the spicule-bearing connective tissue and the muscular sheet surrounding the internal organs.
In the retracted specimen, the heart lies approximately at the level of the posterior end of the pharynx. The heart is a drop-shaped mass of muscle fibers surrounding a central lumen (Figs. 2G and 6). The posterodorsal part of the heart (identified as the auricle) is stained lighter blue owing to fewer muscle fibers and has a circular opening into the surrounding hemocoel that is surrounded by muscular flaps that reach into the lumen of the heart; the anteroventral, conical part (identified to be the ventricle) has a thicker, darker-stained wall with more numerous muscle fibers of which some also traverse the central lumen. Hemolymph flow was reconstructed to be into the auricle and then the ventricle (arrowheads in Fig. 2G). The aorta is a muscular tube projecting from the tip of the ventricle and running anteroventrally, first traversing the muscular sheet and then splitting into two equally thick branches. One branch of the aorta runs into the visceral sac and another branch runs anteriorly, below the esophagus and pharynx; both branches presumably terminate with openings into the lacunae of the hemocoel. The thin-walled muscle layer forming the pericardium is a very spacious sac containing only unstained liquid (primary urine) and lying anteriorly to the heart; the pericardial wall embeds the conical ventricle in its posteroventral side with the area that touches the ventricle forming a vacuolated epicardium (Fig. 2G), presumably the site of ultrafiltration.

The elaborate excretory system extends for about $1 \mathrm{~mm}$ posteriorly of heart and pericardium (Figs. 1F, 3C and 6). The system originates with the short renopericardioduct, a short epithelial tube with particularly strong ciliation forming dark blue staining bundles (Fig. 2F) that connects the lumen of the pericardium to that of the kidney. The kidney is a broadly undulating sac with an internal longitudinal wall that separates a proximal, mostly ventral and a distal, mostly dorsal lumen; both lumina are interconnected in the posterior end of the kidney (position 2 in Fig. 3C) and thus form a duct running first posteriorly and then anteriorly. The proximal lumen is about half as wide as the distal one and has an epithelial lining

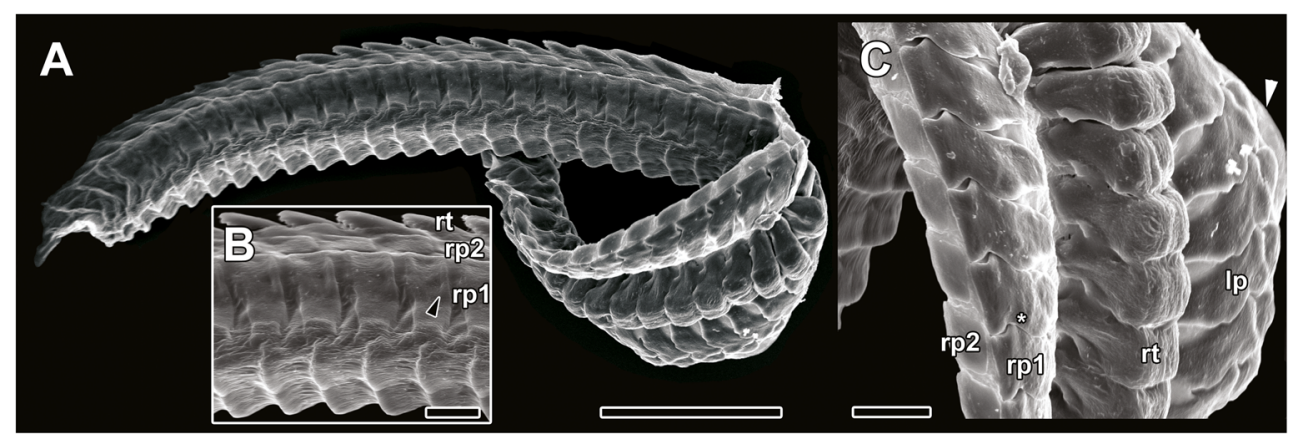

Fig. 4 Scanning electron microscopical images of Wallacellia siputbiru n. gen. n. sp. radula (holotype).(A Complete radula, right view. B Detail of folded upper branch enclosed into radular membrane, right lateral view; arrowhead indicates ventral side of notch in right lateral plate. C Detail of spread lower branch showing teeth in functional position; asterisk shows interacting notch and denticles from two neighboring right lateral plates; note also rhomboid second lateral plates; arrowhead shows free edge of radular membrane bordering left lateral plate (no second plate). Abbreviations: 1p, left lateral plate; rp1, first right lateral plate; rp2, second right lateral plate; rt, rhachidian tooth. Scale bars: (A) $100 \mu \mathrm{m} ;(\mathbf{B}, \mathbf{C}) 20 \mu \mathrm{m}$ 
of regular cells with an unstained vacuole. The distal lumen has a much thicker epithelial lining with taller cells that otherwise resemble those in the first lumen. Adjacent to its origin, the kidney connects to the nephroduct. The ciliated nephroduct (Fig. 2F) is an undulating tube that lies underneath and parallel to the kidney; it first runs posteriorly and then again anteriorly. The anteriormost, distal portion of the nephroduct forms an upward loop that appears to be attached to the pericardial wall for about $200 \mu \mathrm{m}$. After this loop, the nephroduct curves ventrally and opens to the outside via the nephroporus, which lies adjacent to the anus.

\section{Reproductive system}

The reproductive system of Wallacellia siputbiru $\mathrm{n}$. gen. n. sp. is the animals' largest organ system. The hermaphroditic and functionally female components lie in the body cavity/ hemocoel of the visceral sac and functionally male components lie in that of the headfoot. Both areas are interconnected by an epidermal vas deferens.

Gametes are formed in the gonad which fills much of the visceral sac, lying underneath the digestive gland. The gonad is hermaphrodite (ovotestis) and consists of several hundred thin-walled follicles branching from a medioventral, thinly ciliated duct (Fig. 1D). Two to three spherical to oval oocytes (diameter 120-150 $\mu \mathrm{m}$ ) are found in most follicles; each oocyte contains a single large nucleus (staining pale gray) and numerous smaller oval vesicles (presumed yolk, staining intense blue) (Fig. 2A). The estimated number of yolk-rich oocytes in the whole gonad $(3.5 \mathrm{~mm}$ long $\times 1 \mathrm{~mm}$ wide $\times$ $600 \mu \mathrm{m}$ thick) is $1200-1500$. Groups of spermatozoa are found interspersed between the oocytes, often near the base of each follicle. Spermatozoa are present in varying stages of development but generally have a comma-shaped, slightly twisted head sized 1-2 $\mu \mathrm{m}$ and staining dark blue, and an unstained flagellum of at least $25 \mu \mathrm{m}$ length. Spermatozoa generally crowd around a third type of spherical, large cell (presumed nurse cells). The duct into which all follicles discharge (gonoduct) runs anteriorly and curves upward at the anterior end of the gonad (Fig. 10). At the tip of this curve sits an almost spherical ampulla that is formed by an inflated area of the upper wall of the gonoduct. The ampulla contains two oocytes near its base but is otherwise filled with spermatozoa (Fig. 7i). A short piece of thin-walled gonoduct continues from its lower right side; the following parts of the gonoduct constitute the nidamental glands. The voluminous nidamental glands fill the anterior portion of the visceral body cavity and have a very thick epithelium of tall columnar, glandular cells that are filled densely with strongly stained vesicles and discharge into a flat, central lumen. Two areas of nidamental gland, presumably involved in forming various coatings of the egg mass, can be discerned by their morphology and staining properties: the first part ("fg1" in Figs. 3D,D" and 6 originates in the middle of the animal and curves to the right and then back to the middle; its cells stain dark blue. The first half of the first nidamental gland may constitute a separate gland because it is thicker-walled and embeds the receptaculum seminis in its proximal half (putative albumen gland). In this case, the second part of the curve could be referred to as the capsule gland. The receptaculum seminis, the site of recipient sperm (allosperm) storage, is a beanshaped sac connected to the lumen of the first nidamental gland and lies on the right side of the animal (Fig. 3D). The epithelial wall of the receptaculum has a wavy outline with spermatozoa heads closely attached along this surface (Fig. $7 \mathrm{~J}$ ), followed by a broad light blue staining layer of the sperm cell's flagella. Further spermatozoa lying towards the opening of the receptaculum form a dense, purple-stained mass that has a brushstroke-like histological aspect. The second area of nidamental gland ("fg2" in Figs. 3D,D' and 6, putative mucus gland) originates in the middle of the animal and forms a long, flattened sac that curves to the left of the animal; its cells stain dark blue with a distinct purple tint (Fig. $7 \mathrm{H})$. Following the second nidamental gland, the gonoduct turns to the right side again and is again thin-walled and ciliated, yet more muscular towards its end. A short, dorsal leading duct branches near its end and has a slightly widened bulbous tip (presumed bursa copulatrix; head about $600 \mu \mathrm{m}$ away from the genital opening). The end of the gonoduct, the genital opening, is a constricted pore that lies below the right anterior end of the visceral sac, anterior to the anus and nephropore.

The constricted and ciliated vas deferens lies inside an epidermal fold running between dorsal headfoot and foot sole of the right body side and connects the (female) genital opening to the base of the right rhinophores ("male" genital opening). From there, the vas deferens dives into the body cavity of the headfoot, leading again posteriorly and branching to connect to the penial sheath and to the prostate/ejaculatory duct (which in turn connects to the base of the copulatory organ itself). The penial sheath is a large epithelial bag stretching from the anteroventral right to the dorsal left of the visceral cavity (Figs. 1E, F and 3D, D'). Most of the penial sheath wall is a smooth, unciliated epithelium without glands but with a distinct component of basal muscle fibers; this wall is about 10 $20 \mu \mathrm{m}$ thick. On its far left part opposite to the genital opening, the wall has a frilly aspect of many crypts that also contain muscle fibers ("psf" in Figs. 7A and 10); the wall of this frilly part is about $30-50 \mu \mathrm{m}$ thick. In its posterior and ventral part, the wall of the penial sheath has an especially thick layer of underlying muscles, sometimes consisting of a highly regular myoepithelium up to $100 \mu \mathrm{m}$ thick, which when taken together form the huge copulatory apparatus. These evaginations are threefold and form large projections of the penial sheath wall into the lumen of the penial sheath: penis and basal finger lie in the left half of the penial sheath, and the herein termed "grappling" organ (apical part of third lobe of complex 
Fig. 5 Semischematic map of the central nervous system (CNS) of Wallacellia siputbiru n. gen. n. sp., posterodorsal view, anterior to the top. Based on reconstruction of paratype. Fully schematic map at lower right.

Abbreviations: bcm, buccal commissure; bg, buccal ganglion; cbc, cerebro-buccal connective; ccm, cerebral commissure; cg, cerebral ganglion; cgl, "gland" above cerebral commissure; ey, eye; gn, genital nerve; gog, gastroesophageal ganglion; lpag, left parietal ganglion; lplg, left pleural ganglion; ltn, labial tentacle nerve; npag, parietal nerve; lvc, long connective of visceral loop; on?, putative oral nerve; opn, optic nerve; opg, optic ganglion; osg, osphradial ganglion; osn, osphradial nerve; pcm, pedal commissure; pg, pedal ganglion; pn1-pn4, pedal nerves; rhg, rhinophoral ganglion; rhn, rhinophoral nerve; rn, radular nerve; rpag, right parietal ganglion; rplg, right pleural ganglion; sc, statocyst; subg, subintestinal ganglion; supg, supraintestinal ganglion; vg, visceral ganglion; vn, visceral nerve

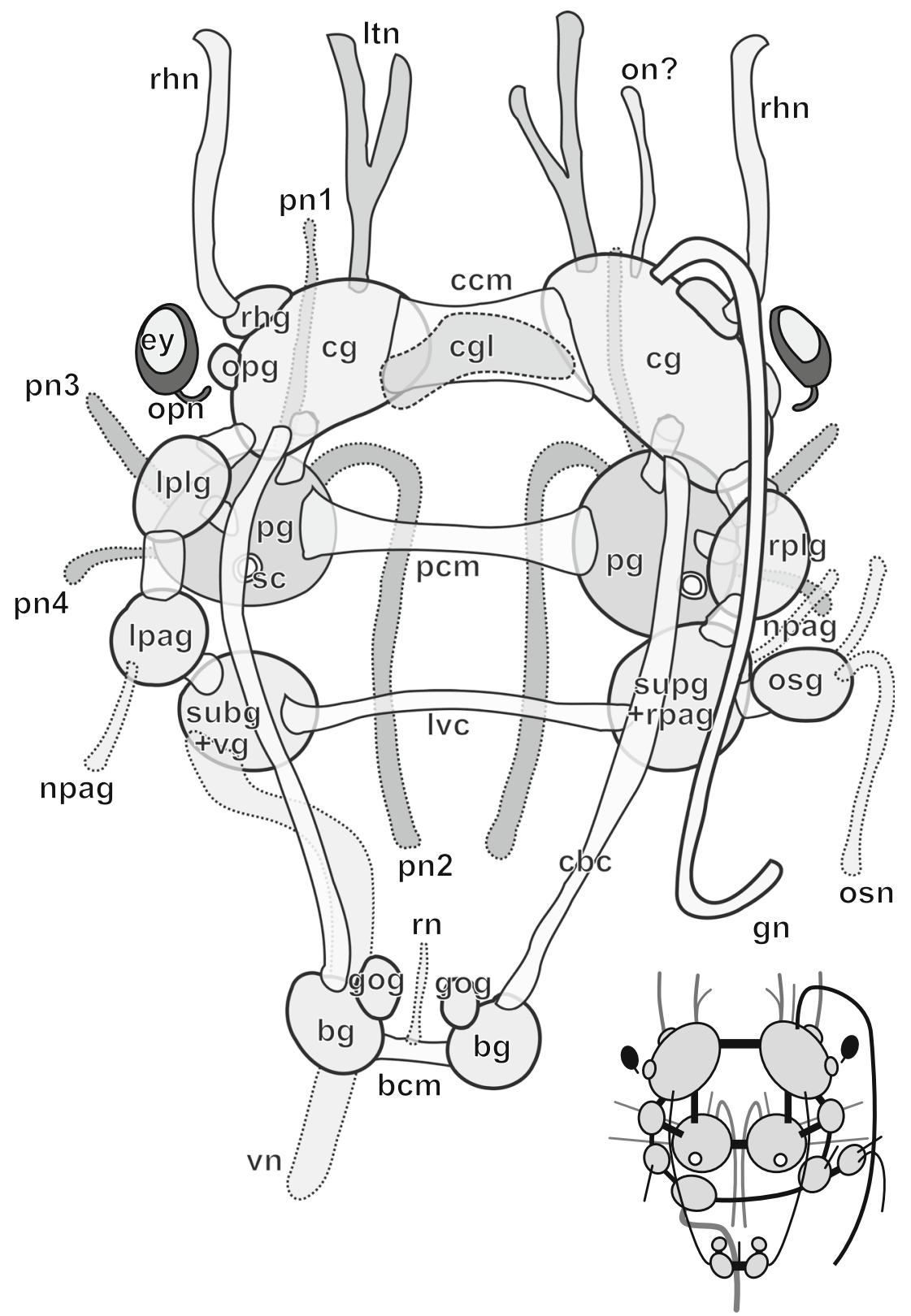

"rapto-penis" as of Schrödl and Neusser 2010) lies in the right half. Each of the three parts has distinct hook-or stylet-like elements (cuticularized areas? See "Discussion"). The penis and basal finger are solid structures and are traversed by epithelial ducts that originate in a glandular tube discharging through their tips; these glandular structures coil behind and to the left of the penial sheath. The grappling organ is hollow inside and lacks an opening, epithelial duct, or associated gland.

The first component of the copulatory organ is the penis which is conical, about $600 \mu \mathrm{m}$ tall, with a flattened tip pointing posteriorly in situ (Figs. 8A, B, C, F and 10). The ejaculatory opening lies dorsally and is partially obscured by a flap of epidermis (Fig. 7A). Immediately to its right and towards the base of the penis lies a deep gutter-like fold, the left wall of which bears an approximately only $250 \mu \mathrm{m}$ long, boomerang-shaped layer of cuticle (Figs. 7A and 8A, C, F) with a broad base anchoring to the underlying muscles. This cuticle (termed "comb" herein) bears many small spines along its edge that are directed dorsally and away from the penis, forming a serrated margin of the aforementioned gutter. SEM examination shows at least 100 small spines sized 10-60 $\mu \mathrm{m}$ (Fig. 9D, D'). A small epithelial duct, opening between comb and ejaculatory opening, leads blindly into the penis and between a small aggregation of potentially glandular cells (Figs. 7A and 10). The left side and tip of the penis are also filled with potential gland cells that contain many vesicles and stain light blue (Fig. 7C), but no opening(s) or collecting duct could 


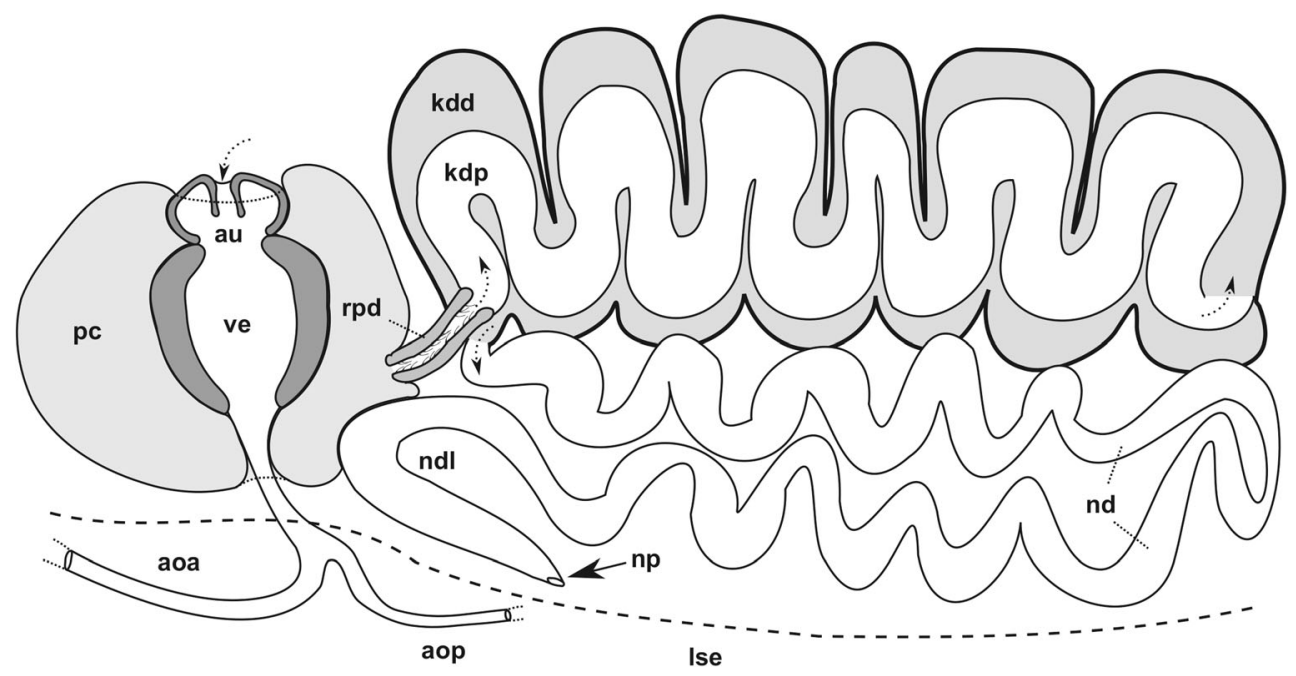

Fig. 6 Scheme of the circulatory and excretory systems of Wallacellia siputbiru n. gen. n. sp., left lateral view. Based on reconstruction of paratype. Arrows indicate presumed direction of hemolymph flow into the heart and primary urine in the kidney. Abbreviations: aoa, anterior branch of aorta; aop, posterior (visceral) branch of aorta; au, auricle; kdd, distal lumen of kidney; kdp, proximal lumen of kidney; lse, longitudinal muscle septum separating peripheral and central sinuses; nd, nephroduct; $\mathrm{ndl}$, loop of nephroduct touching pericardium; np, nephropore; pc, pericardium; rpd, renopericardioduct; ve, ventricle discerned. The penial musculature itself is complex and transversed by the distalmost ejaculatory duct. This epithelial duct curves through the penis where it is unciliated and has a strong muscular lining (upper part of Fig. 7C). Following the ejaculatory duct proximally, it then emerges from the base of the penial sheath where it becomes thicker and is surrounded by muscular layers with vacuoles (lower part of Fig. 7C); the wall is irregular and contains what appears to be many microscopic vacuoles (Fig. 7D). This area of the ejaculatory duct is unusual in two ways: first, it is also surrounded by a roughly spherical, irregular mass (Figs. 8A, B, F and 10) of what might be glands, connective tissue, or smooth subepithelial muscle with unstained, regular, and narrow cells (termed "basal muscle" here; Fig. 7C, D). Second, the wall of the ejaculatory duct here is duplicated from its proximal end, forming a thin and whip-like secondary duct that coils inside the primary duct. This secondary duct (termed "penial stylet" herein; "pst" in Figs. 7, 8 and 10) has a smooth outer epithelium, an inner epithelial duct that is even thinner but identical in histology, and coin-stack like series of regular subepithelial cells, possibly smooth muscle cells (Fig. 7D). This penial stylet is in total about 1.6-mm long, coiled inside the basal muscle bulb, tapering to a thin tip where the internal duct opens, and is directed towards the ejaculatory opening of the penis. The stylet is broadest at its base where its inner lumen is continuous with the continuing, even more proximal ejaculatory duct that emerges from the basal muscle bulb. From there, the remaining ejaculatory duct forms a mass of loose coils in the hemocoel behind the penial sheath (Fig. 7D), with three histologically distinct parts: the first and most distal is thin and ciliated (diameter about $50 \mu \mathrm{m}$; left part in Fig. 10), the second becomes thicker and glandular with blue-staining vacuoles (diameter about $90 \mu \mathrm{m}$; "edp" in Fig. 7C, H, middle part in Fig. 10), and the third and most proximal forms the large and tubular prostate which lies to the left of the penial sheath. The prostate (diameter $280 \mu \mathrm{m}$; "pr" in Figs. 2 and 8) is about 1$\mathrm{mm}$ long and has many columnar glandular cells with microscopic blue vesicles (Fig. 7G) that surround a central, ciliated, and round lumen. The most proximal end of the prostate leads to a thin duct that constitutes the earlier mentioned posteriorleading vas deferens, ending the backward reconstruction of the sperm pathway from the ejaculatory opening to the base of the right rhinophore.

The second component of the copulatory organ, the basal finger, is a u-shaped muscular structure lying to the left of the penis (Fig. 8A, B, D, F and 10). The short limb of the basal finger is finger-shaped, about $300-\mu \mathrm{m}$ tall, with a rounded tip pointing anteriorly in situ (Fig. 7A, E). The basal finger musculature is more uniform than that of the penis, consisting mainly of smooth crossing muscle fibers. The tip of the short limb is equipped with a stout cuticular stylet that stains dark blue (Fig. 7C, E). This basal finger stylet is hollow, about $200-\mu \mathrm{m}$ long (not observed in SEM), slightly curved, with a pointed tip that has a terminal pore opening to the inside (arrowhead in Figs. 7E, 8E) and some sharp crenulations of $5-10-\mu \mathrm{m}$ size just behind the tip (Fig. 7E). The lumen of the basal finger stylet connects to a thin epithelial duct that, similar to the ejaculatory duct in the penis, traverses the musculature of the short limb of the basal finger and emerges from the left sides of the penial sheath. This duct (paraprostatic duct "ppd" in Figs. 8 and 10) coils first between the thin proximal ejaculatory duct and then leads into a glandular paraprostate. The paraprostate (diameter 100-450 $\mu \mathrm{m}$; "ppr" in Figs. 2 and 8 ) is about $3.5-\mathrm{mm}$ long, lies in a loop behind the penial 


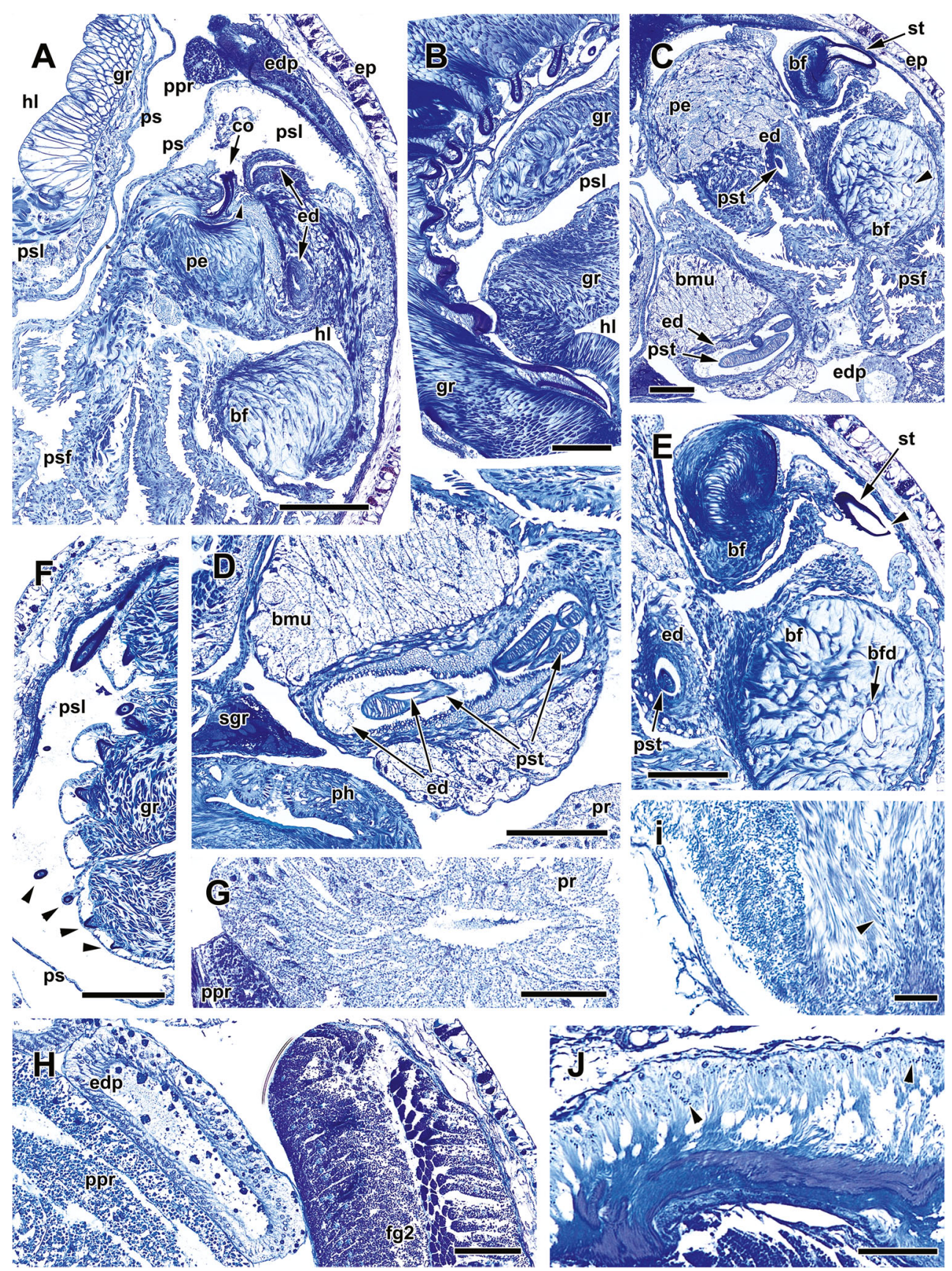

Fig. 7 Semithin histological sections of Wallacellia siputbiru $n$. gen. n. sp. paratype showing aspects of reproductive system. All cross sections, anterior view, dorsal side up. A Left half of penial sheath showing the penis near ejaculatory opening and basal finger (slice 252); arrowhead indicates opening of intrapenial gland. B Right half of penial sheath showing ten thorns belonging to first row on tip of (inverted) grappling organ (slice 294). C Left half of penial sheath showing the penis and basal finger; arrowhead indicates lumen of blind duct inside basal finger (slice 294). D Basal bulb of the penis with looping penial stylet inside proximal ejaculatory duct (slice 303). E Basal finger; arrowhead indicates opening of basal finger stylet (slice 303). F Ten spines on the base of grappling organ (slice 132). G Prostate (slice 225). H Detail of reproductive tract glands on the left side of the body (slice 439). (i) Detail of unsorted spermatozoa in ampulla, head indicated by arrowhead (slice 600). J Detail of sorted spermatozoa in receptaculum seminis, head indicated by arrowhead (slice 624). Abbreviations: bf, basal finger; bfd, blind duct in basal finger; bmu, basal muscular bulb of the penis (outside penial sheath); co, cuticular comb on the penis; ed, ejaculatory duct; edp, proximal ejaculatory duct (glandular); ep, epidermis; fg2, second female/ nidamental gland; gr, myoepithelium of grappling organ wall; hl, hemolymph space (sinus of body cavity); pe, penis; ph, dorsal side of pharynx; pr, prostate; ps, penial sheath; psf, folded area of penial sheath; psl, lumen of penial sheath (connected to exterior of animal); pst, retracted penial stylet; ppr, paraprostate; sgr, right salivary gland; st, stylet of basal finger. Scale bars: (A, B, C, D, E, F) $100 \mu \mathrm{m}$; (G, H, J) $50 \mu \mathrm{m}$; (I) $25 \mu \mathrm{m}$ 


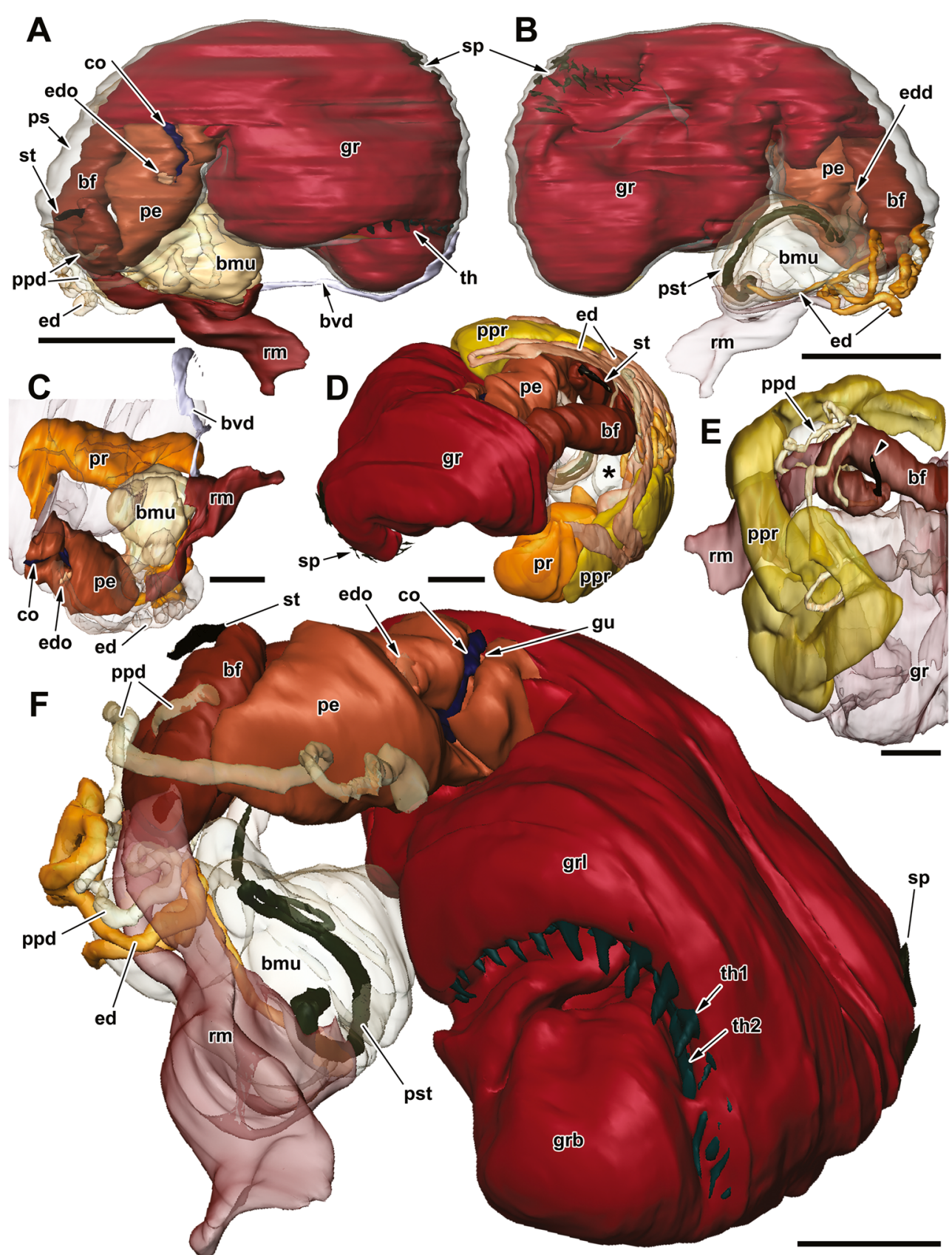

Fig. 8 3D reconstructions of Wallacellia siputbiru n. gen. n. sp. copulatory organ (paratype). A Complete copulatory organ, dorsal view, anterior up. B Complete copulatory organ, ventral view. C Components of the penis/prostatic system, dorsal view, anterior to left - other components not shown. D Complete copulatory organ, penial sheath removed, anterior left view; asterisk shows position of basal bulb of the penis lying underneath. E Components of basal finger/paraprostatic system, dorsal view, anterior to right; arrowhead highlights opening of stylet. F Complete copulatory organ and all cuticular components, without penial sheath and glandular tubes of prostate and paraprostate, posterior right view. Abbreviations: bf, basal finger; bmu, muscular bulb at base of the penis; bvd, posterior-leading vas deferens; co, cuticular comb adjacent to ejaculatory opening; ed, ejaculatory duct; edd, distalmost piece of ejaculatory duct; edo, opening of ejaculatory duct; gr, muscular grappling organ; grb, bulbous tip of grappling organ; grl, "lip" of grappling organ carrying two rows of cuticular thorns; gu, gutter adjacent to cuticular comb on penis; pe, penis; ppd, paraprostatic duct; ppr, paraprostate; pr, prostate; ps, penial sheath; pst, retracted penial stylet; $\mathrm{rm}$, retractor muscle of copulatory organ; sp, cuticular spines at base of grappling organ; st, hollow cuticular stylet of basal finger; th1, cuticular thorn of grappling organ, outer row; th2, broad cuticular thorn of grappling organ, inner row. Scale bars: (A, B) $500 \mu \mathrm{m}$; (C, D, E, F) $250 \mu \mathrm{m}$ sheath, and ends blindly on the left side of the animal. The paraprostate has many columnar glandular cells with dark blue staining, round vesicles that are larger than those of the nidamental glands or the prostate (Fig. $7 \mathrm{H}$ ) and surround a broad and flat lumen. The paraprostatic secretion is presumably transported from the proximal paraprostate through the 
Fig. 9 Scanning electron microscopical images of cuticular hard parts of copulatory organ of Wallacellia siputbiru $\mathrm{n}$. gen. $\mathrm{n}$. sp. (holotype) and 3D reconstructions in situ (paratype). A Isolated cuticular thorn of grappling organ tip (apical row). B Two articulated thorns of upper (top, long base) and lower row (below, short base) of grappling organ tip. C Three isolated spines of grappling organ base. D Cuticular "comb" from the penis. D' Detail of spinelets on cuticular comb. E Reconstructions of each group of cuticular elements in situ, individual plane views. Basal finger and penial stylets not observed in SEM. Abbreviations: co, cuticular comb of penis; $\mathrm{sp}$, group of spines on base of grappling organ; st, stylet of basal finger; pst, retracted and partially enrolled penial stylet; th1, row of thorns of basal row; th2, row of thorns of apical row. Scale bars: $\left(\mathbf{A}, \mathbf{B}, \mathbf{C}, \mathbf{D}^{\prime}\right) 20 \mu \mathrm{m}, \mathbf{E} 100 \mu \mathrm{m}$

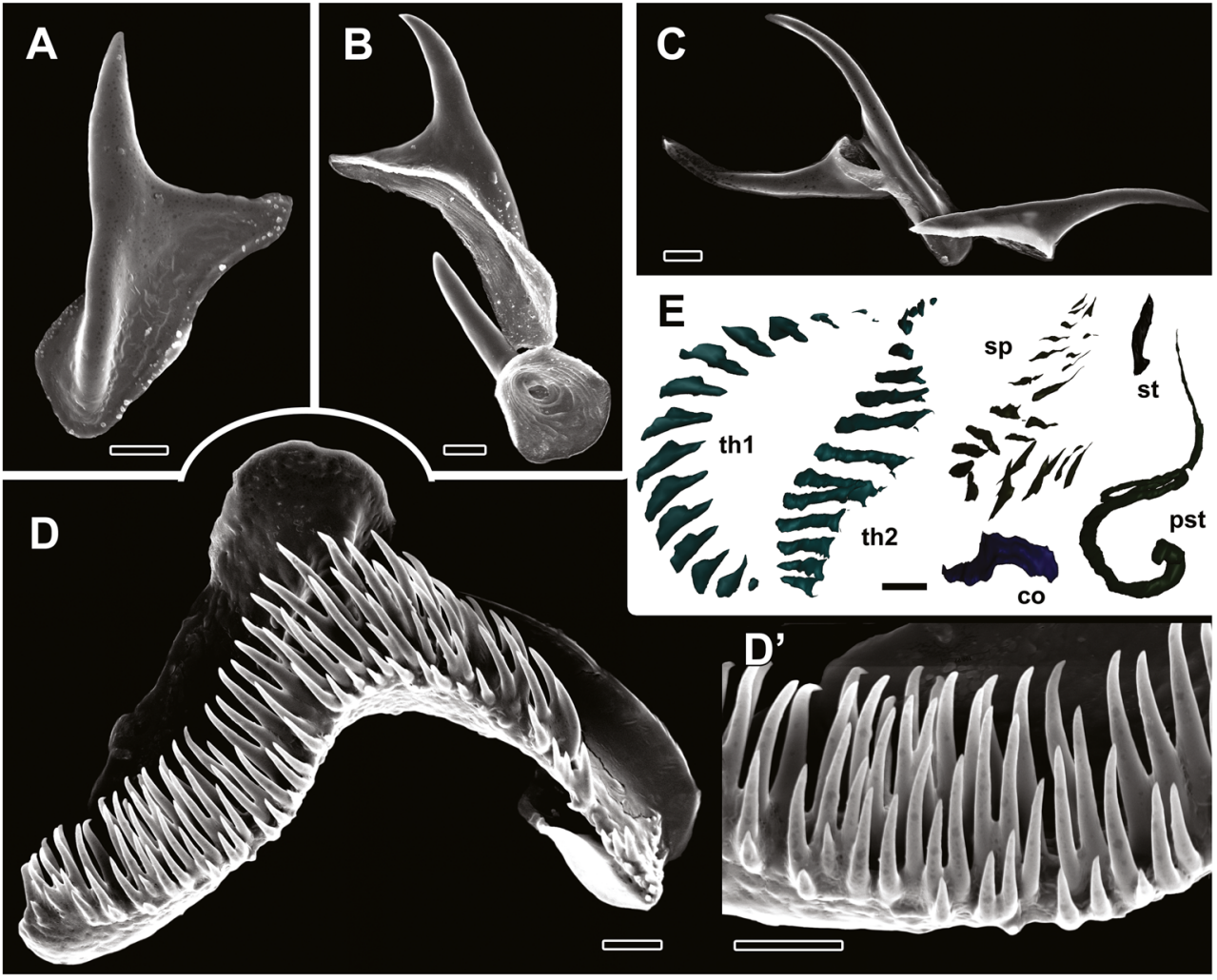

paraprostatic duct and discharged through the distal stylet of the basal finger. The long limb of the basal finger is about $500-\mu \mathrm{m}$ long, is slightly curved, and has a curious epithelial duct on its left side: this duct (arrowhead in Fig. 7C, "bfd" in Fig. 7E) ends blindly, is unciliated, and is not evidently connected to any internal structure except that some muscle cells possibly radiate from it. This left part of the basal finger bears no further structures but is continuous with the base of the grappling organ.

The third and last component of the copulatory organ, the grappling organ, is a huge and largely drop-shaped structure that originates from the long limb of the basal finger on the left side and reaches into the complete right half of the penial sheath. The grappling organ is about $1.4-\mathrm{mm}$ tall and $900-\mu \mathrm{m}$ wide and has a bulbous tip in situ lying in the posterior right of the penial sheath (Figs. 1E, 8A, B and 10). The entire structure is formed by an evagination of the penial sheath wall and is thus hollow inside. Not much free space surrounds the grappling organ inside the penial sheath ("psl" in Fig. 7A). As mentioned earlier, the walls of the grappling organ consist of a thin and unciliated epidermis and a thick presumed myoepithelium consisting of regular, tall cells (Fig. 7A, B) or more longitudinal fibers (Fig. 7F). A voluminous hemolymph space lies underneath the myoepithelium and extends into the tip of the organ ( $\mathrm{hl}$ in Fig. 7A, B). The anteroventral right corner of the grappling organ has a liplike extension that bears a field of spines that stain dark blue
(Fig. 8A, B, D). This field of spines is curved ("sp" in Fig. 9) and bears two rows of sharp cuticular spines. There are 14 spines along the outer side of the curve and 10 along its inner side; each spine is about $120-\mu \mathrm{m}$ tall and $20-\mu \mathrm{m}$ thick, with a base that is about $70-\mu \mathrm{m}$ wide (Fig. 9C). The spines extend from the myoepithelium below the thin epithelium of the grappling organ and into the lumen of the penial sheath (Fig. 7F); they are hollow inside and filled with cells similar to those in the penial stylet, arranged in coin-stack like series. The bulbous tip of the grappling organ is slightly inverted. It has a subterminal and semilunar fold on its dorsal side (Fig. 8A, F) that, on its outer "lip," carries two additional rows of large, thorn-like cuticular elements: the outer row consists of 14 strong thorns (up to about $100-\mu \mathrm{m}$ tall, with rounded base about $50-\mu \mathrm{m}$ wide; Fig. 7B, "th1" in Figs. 8F and 9E). The inner, more apical row has 14 or 15 thorns that are much more triangular in side view (also up to $100-\mu \mathrm{m}$ tall, but with elongate base up to around 300 long). The thorns resemble the spines, the basal finger stylet, and the penial "comb" in histology.

Long muscle fibers radiate from the long limb of the basal finger and the base of the basal muscle bulb of the penis into the thick retractor muscle. The retractor muscle itself consists of parallel bundles of long, smooth muscle cells (Fig. 2E) and runs posteroventrally; at its base it merges with the muscular diaphragm and the many muscle fibers radiating from there (Fig. 10). 


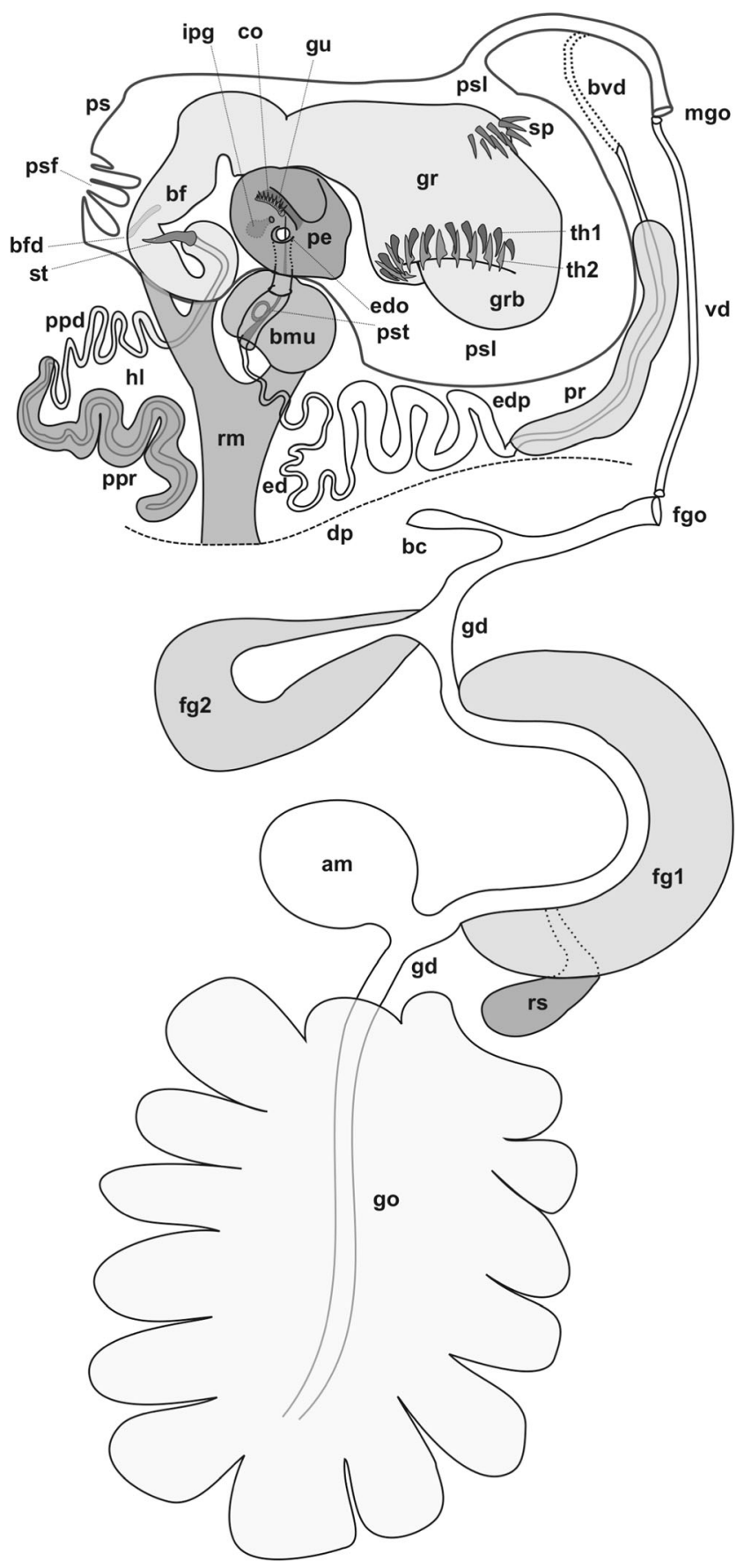

\section{Discussion}

Wallacellia siputbiru n. gen. n. sp. is the third freshwater acochlidian genus described from the island of Ambon, Indonesia, after Acochlidium amboinense and Strubellia paradoxa. All three are thus the type species of their respective genera. Other species in these genera are known to occur between Indonesia, Fiji, and Palau (Acochlidium) and from Indonesia to Vanuatu (Strubellia) (Jörger et al. 2014b). The still enigmatic genus Palliohedyle is known only from eastern Indonesia (Jörger et al. 2014b). Wallacellia siputbiru n. gen.
Fig. 10 Scheme of the reproductive system of Wallacellia siputbiru n. gen. n. sp., dorsal view. Based on reconstruction of paratype. Abbreviations: am, ampulla; bc, bursa copulatrix; bf, basal finger; bfd, blind duct inside basal finger; bmu, basal muscle of penis; bvd, posteriorleading vas deferens (stippled area not observed); co, cuticular comb on penis; dp, transversal muscular diaphragm separating body cavities of headfoot and visceral sac; ed, ejaculatory duct; edp, proximal, glandular part of ejaculatory duct; edo, ejaculatory opening; fg1, proximal female/ nidamental gland; fg2, distal female/nidamental gland; fgo, female gonopore; gd, hermaphroditic gonoduct; go, gonad (ovotestis); gr, grappling organ; grb, bulbous tip of grappling organ; gu, gutter adjacent to cuticular comb on penis; hl, hemolymph spaces; ipg, intrapenial gland; mgo, male gonopore; pe, penis; ppd, paraprostatic duct; ppr, paraprostate; pr, prostate; ps, penial sheath; psf, strongly infolded area of wall of penial sheath; psl, lumen of penial sheath; pst, penial stylet; rm, retractor muscle of copulatory organ inserting on diaphragm; rs, receptaculum seminis; sp, cuticular spines on base of grappling organ; st, cuticular stylet of basal finger; th1, basal row of cuticular thorns; th2, apical row of cuticular thorns; vd, vas deferens

n. sp. may occur in a larger geographic area. However, several independent surveys of similar localities in Indonesia never found it, indicating that this charismatic new species may be rare, endemic to the Moluccas or at least Indonesia. It may thus be an endangered species due to its geographic restriction, rarity, and special habitat.

Previous molecular phylogenetic study (Jörger et al. 2014b) showed that Wallacellia siputbiru n. gen. n. sp. is the wellsupported sister taxon to Acochlidium and Palliohedyle, and Strubellia is the sister to these three genera. Neusser et al. (2016) placed Wallacellia as sister to Palliohedyle, albeit with lower statistical support. Wallacellia $\mathrm{n}$. gen. may therefore present a useful "missing link" in the reconstruction of acochlidiid evolution. The marine interstitial and brackish-water Pseudunelidae were robustly recovered as sister group to Acochlidiidae (Fig. 11; Jörger et al. 2010, 2014b, Neusser et al. 2011b), suggesting a marine and interstitial origin for the family Acochlidiidae. The relationships of other Acochlidioidea (previously also: Hedylopsacea sensu Wawra 1987) are to date less robustly resolved (Neusser et al. 2011a, b, 2016) and some described taxa have not been sequenced yet (Neusser and Schrödl 2007; Drainas et al. 2018). We here compare the anatomy and function of major organ systems of Wallacellia siputbiru n. gen. n. sp. with that of other Acochlidioidea, focusing on Acochlidiidae and Pseudunelidae, and discuss the evolution of their copulatory organs.

\section{External morphology, habitat, and feeding ecology}

Wallacellia siputbiru $\mathrm{n}$. gen. n. sp. has the morphology typical of aquatic acochlidians, with a free visceral sac and two pairs of head tentacles (shortened in some subgroups; Schrödl and Neusser 2010). Size (around $1 \mathrm{~cm}$ ), shape, and habitat identify it as an unequivocal member of Acochlidiidae. The body 


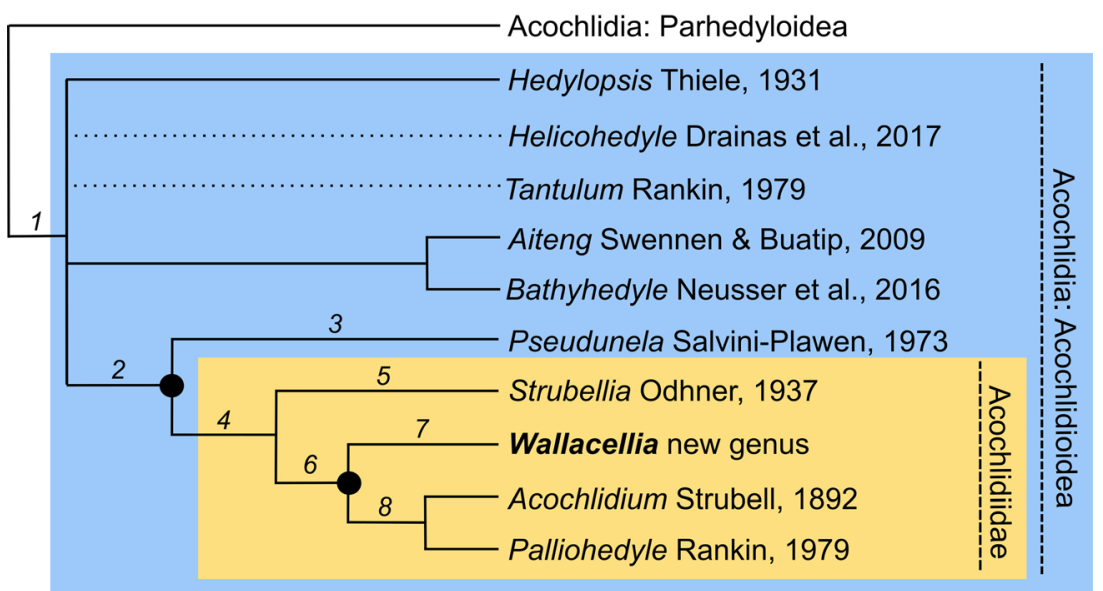

Fig. 11 Relationships and synapomorphies of Acochlidiidae including Wallacellia siputbiru n. gen. n. sp. Schematized topology based on Jörger et al. (2014b), Neusser et al. (2016) (position of Bathyhedyle), Drainas et al. 2018 (position of Helicohedyle), and Schrödl and Neusser 2010 (position of Tantulum and some synapomorphies). Black circles indicate strong support in the phylogenetic analysis of Jörger et al. (2014b), bootstrap values above 97). Numbers indicate synapomorphies of the respective clades. Clade 1 (Acochlidioidea): large kidney (?), sperm head short (?). Clade 2 (Acochlidiidae plus Pseudunelidae): upper shore habitat? Separate injection devices of the basal finger and penis. Kidney with long, looping nephroduct. Externally visible bulb in area of heart. Clade 3 (Pseudunelidae): loss of bursa copulatrix(?). Clade 4 (Acochlidiidae): benthic and freshwater habitat, large body size, pigmented body, rhachidian tooth margin with $30+$ small denticles per side, food: egg capsules of Neritidae, receptaculum seminis reinstated?, syrinx-like renopericardioduct, penis with apical cuticle. Clade 5
(Strubellia): reddish-brown color, penis without stylet but with hook, basal finger stylet long and longitudinally enrolled, copulatory organ lost later in ontogeny (protandry), open seminal groove. Clade 6 (Wallacellia gen. nov. + Acochlidium + Palliohedyle): some greenish coloration, mask-like pigment on headfoot (?), visceral sac flattened, penial stylet long and retractable, "grappling organ" with thorns and spines. Clade 7 (Wallacellia gen. nov.): mask-like pigment on headfoot faint (?), right rhinophore enlarged (?), foot corners not flaring, visceral sac slightly flattened, penis with cuticular comb, penis with underlying bulb, penial stylet retractable, grappling organ with 14 spines and 28 thorns. Clade 8 (Acochlidium + Palliohedyle): mask-like pigment, some white spots, visceral sac flattened and leaf-shaped (Palliohedyle: with curling margins), ampulla/renopericardioducts/gonad lobes/digestive gland lobes multiplied, secondary loss of receptaculum seminis and bursa copulatrix, hypodermic injection of sperm, grappling organ with 10 spines and 16-18 thorns. Data on Palliohedyle internal anatomy are largely deficient shape is principally as in Strubellia or Pseudunela species. Wallacellia siputbiru n. gen. n. sp. differs from other acochlidiids in details of the shape of the foot (not with projecting anterior corners but round) and the shape of the visceral sac (only slightly flattened, neither round in cross section as in Strubellia nor "leaf-shaped" as in Acochlidium/ Palliohedyle, see below) (Table 1). Presence of an enlarged right rhinophore was not previously reported for any other acochlidian but we believe this is only a temporary feature associated with copulation; still, this feature should be critically reinvestigated in additional material of the species or in other acochlidiids where it was never observed so far. Otherwise the tentacles are as in other acochlidiids, including an internal and presumably stabilizing layer of spicules (Brenzinger et al. 2011b). The genus furthermore differs externally from other acochlidiids in the namesake blue-green coloration of the headfoot and visceral sac: Strubellia species are uniformly reddish-brown to orange, whereas Acochlidium species are brownish anteriorly and have an orange-brown to dark green visceral sac (Strubell 1892, Wawra 1979, Brenzinger et al. $2011 \mathrm{~b}$, Jörger et al. 2014b, own observations). Occasionally occurring Acochlidium individuals with aberrant bright green to reddish color were found to be genetically identical (own unpublished data). However, we do not consider the present specimens of Wallacellia siputbiru $\mathrm{n}$. gen. $\mathrm{n}$. sp. to be abnormally colored. Living Acochlidium have distinct black pattern on their headfoot, leaving a cross-shaped unpigmented region in the middle (e.g., Haynes and Kenchington 1991; Jörger et al. 2014b). The existing photos of Wallacellia siputbiru n. gen. n. sp. hint at a similar yet weaker pattern (Fig. 1C) but no melanin granules could be found in corresponding parts in the histological sections. New photographs of living specimens would be needed to confirm the presence or absence of this "mask"-like pattern like in Acochlidium.

Wallacellia siputbiru $\mathrm{n}$. gen. $\mathrm{n}$. sp. was found in a stream specifically surveyed for freshwater gastropods and acochlidiid slugs and can be assumed to have highly similar habitat requirements to other acochlidiids, although these requirements are not fully known. In Vanuatu, Haynes (2000) found Strubellia only in a few streams in limestone areas, but later surveys also found it in other areas (see Brenzinger et al. 2011b). In Fiji, Haynes (1988) found gastropods to be the most diverse and dominant in streams with strong flow and reported Acochlidium only from one stream on a comparatively steep coast. Acochlidiids generally cooccur with equally amphidromous Neritidae, herbivorous snails which often form an abundant part of the gastropod 
fauna in coastal streams of Indo-Pacific islands (Haynes 1988). Abundance of amphidromous neritids in the IndoPacific seems to be directly related to the slope of the adjacent coast, with shallow coasts and slow-moving streams appearing less suitable for these snails that need their larvae to be swept out into the ocean (Davis and Ponder 2019). Neritidae deposit calcareous egg capsules onto all kinds of hard substrate including stones, wood, or the shells of other gastropods (Kano and Fukumori 2010; Kano et al. 2013). Each egg capsule contains numerous embryos and yolky substance but is protected with a thick outer layer of mineral particles derived from the food (Kano and Fukumori 2010). In experimental settings, Strubellia wawrai was observed to eagerly feed on these egg capsules but to reject other food (Brenzinger et al. 2011b). The same behavior and food preference was observed for Acochlidium (Neusser, Brenzinger, pers. obs.). In both cases, a small hole appears to be created in a capsule's wall with the radula through which the contents are sucked out. This piercing and sucking mode of feeding, the mineralized nature of the capsule wall, and the highly nutritious and digestible food likely explain some anatomical features found earlier in Strubellia and Acochlidium (Brenzinger et al. 2011b, Neusser in prep.): the strong wear of the rhachidian teeth, the chain-like structure of the interlocking lateral plates, the presence of large salivary glands with pump-like salivary reservoirs, and perhaps also the presence of spicules around the pharynx (stabilizers) and the simple intestine and lack of a stomach. All these features are also present in Wallacellia $n$. gen. and the same mode of egg capsule feeding can be assumed. Still, some still underappreciated variation may exist in the family: some Acochlidium species apparently have a slightly broader rhachidian tooth with either larger (Bergh 1895) or smaller to no denticles (Haynes and Kenchington 1991), indicating possible variation in the choice of egg capsules and further niche differentiation. Thick cuticularized ridges in the anterior pharynx, as shown here for Wallacellia n. gen., were not reported for other acochlidiids but a thin cuticle is generally present (Brenzinger et al. 2011b), so this probably does not constitute a generic difference but may warrant further examination using scanning electron microscopy. A finely serrated rhachidian tooth is apomorphic for Acochlidiidae, but the chain-like linked laterals are also found in other acochlidians (Neusser et al. 2011a, b, 2016). The presence of co-occurring neritids may thus be the most important habitat requirement for Acochlidiidae; co-evolution of at least some Acochlidimorpha and Neritidae with similar habitats was previously suggested (Neusser et al. 2016). Other cooccurring gastropods are brooders and thus no likely targets of predation by Acochlidiidae (Thiaridae; Glaubrecht and Neiber 2019). Likewise, interspecific competition (Turner et al. 2007) or substrate preferences (Glaubrecht 2011) may affect habitat choice of acochlidiids, as suggested for other freshwater gastropods. These various scenarios remain to be examined in the case of Acochlidiidae.

\section{Central nervous system structure}

The central nervous system of Wallacellia siputbiru $\mathrm{n}$. gen. $\mathrm{n}$. $\mathrm{sp}$. has the same number of ganglia as that of the acochlidiid Strubellia wawrai and the ganglia and sensory organs have the same position and shape (see Brenzinger et al. 2011a: Fig. 3). Several small features (double connectives of rhinophoral ganglion, Hancock's nerve, several thin nerves innervating the digestive tract) described for $S$. wawrai were not found in Wallacellia siputbiru n. gen. n. sp. but further material, preferably fixed after relaxation in magnesium chloride, is necessary to confirm their lack or presence. Existing descriptions of Acochlidium nervous systems (Bücking 1933) are insufficient to compare minute details to our study. We would expect sensory Hancock's organs to be present in Wallacellia as they were detected in all other acochlidians. A sensory osphradium, known for Strubellia (Brenzinger et al. 2011b), was so far not detected for Acochlidium and its presence needs to be confirmed in Wallacellia; if lost, it might be autapomorphic for these two genera.

The loose patch of connective tissue above the cerebral commissure (shown in Figs. 3 and 5) was also described for Strubellia species (Brenzinger et al. 2011a) who suggested it to be a possible endocrine gland. Such glands are found in various panpulmonates (van Mol 1967, see Haszprunar and Huber 1990) and hence the identity of this structure warrants further study. Similar cells may also be (plesiomorphically?) present in the interstitial Asperspina Raenkin, 1979 (see Neusser et al. 2007).

The layout of the nervous system in Acochlidimorpha varies mainly in the presence of accessory ganglia on the cerebral nerves (in many interstitial species, e.g., Jörger et al. 2008) or the number of free ganglia in the visceral loop (e.g., Tantulum, Aiteng, and Bathyhedyle - again plesiomorphically? - have four, the remainder including Wallacellia siputbiru n. gen. n. sp., three; Neusser and Schrödl 2007, Neusser et al. 2011b, 2016).

\section{Circulatory and excretory adaptations to freshwater}

Life in freshwater requires specific adaptations to ion homeostasis (Ruppert et al. 2003; Schmidt-Rhaesa 2007a). The heart and kidney of freshwater acochlidiids and brackish-water Pseudunela espiritusanta (Neusser and Schrödl 2009) were discussed to be enlarged or modified with respect to marine acochlidians (Neusser et al. 2011b), likely being adaptations to life in freshwater. The heart and kidney of Wallacellia siputbiru n. gen. n. sp. appear to be identical to that of Strubellia paradoxa or S. wawrai (Brenzinger et al. 2011a, 2011b): the ventricle is enlarged and has a thick epicardium, 
a part of the pericardium hypothesized to be the site of ultrafiltration (Küthe 1935; Brenzinger et al. 2011b) and thus apparently hypertrophied. The renopericardioduct is thick and also has particularly strong compound cilia that are not found in marine and brackish-water Pseudunelidae. This condition resembles the apomorphically enlarged renopericardioduct of (marine) nudibranch sea slugs which is also termed "syrinx" (Schrödl and Wägele 2001; Dayrat and Tillier 2002, and Schrödl and Neusser 2010). Acochlidium species have identically strong renopericardioducts that even are secondarily multiplied and form many parallel openings from the pericardium into the kidney (Bücking 1933, Neusser et al. in prep.; pers. obs.), again likely boosting excretory capabilities. In addition, Acochlidium species have a network of parallel dorsal vessels (Bücking 1933, see Neusser et al. 2018), a branching digestive gland, gonad, and ampulla - all conditions not found in Wallacellia siputbiru n. gen. n. sp., Strubellia, and Pseudunela. Acochlidium (and Palliohedyle?) stand out among acochlidians in having modified their visceral sac and its internal organs, including the posterior reproductive system. It remains to be understood if these unique further adaptations enhance gas or ion exchange or if they play a different role.

\section{Reproductive system}

Acochlidimorpha belong to the gastropod "subclass" Heterobranchia and heterobranchs are principally hermaphrodites (Haszprunar 1985). In fact, some of the only exceptions from this rule are found among acochlidians: interstitial Ganitus Marcus, 1953 and other members of the Parhedyloidea have wholly separate sexes (see Schrödl and Neusser 2010), and freshwater Strubellia was reconstructed to be functionally male in its early life but is thought to later reduce its copulatory organ and remain functionally female (Wawra 1988; Brenzinger et al. 2011a). Hermaphroditic slugs generally have three vesicles in the visceral body cavity that function in storage of spermatozoa (Beeman 1977): (1) the ampulla that stores own mature spermatozoa (autosperm) and lies in the proximal, beginning part of the gonoduct; (2) the bursa copulatrix that receives, stores, and even digests foreign spermatozoa (allosperm) and spermatophores during and after copulation and generally lies in the distal, ending part of the gonoduct near the genital opening; (3) the receptaculum seminis that stores and nurtures a subset of allosperm and lies again in the proximal gonoduct, adjacent to where fertilization of ripe oocytes takes place. Receptaculum and bursa morphology may reflect copulatory behavior and vary among Acochlidimorpha: a receptaculum was not reported for most acochlidians closely related to Wallacellia siputbiru $\mathrm{n}$. gen. n. sp. except for Strubellia (Fig. 10, Table 1, see Brenzinger et al. $2011 \mathrm{a}, \mathrm{b}$ ) and some of the larger-bodied Pseudunela (see Neusser et al. 2011b) but may have simply been overlooked due to its small size. A bursa copulatrix, small in Wallacellia siputbiru n. gen. n. sp., is generally present in other acochlidians but was shown to be reduced later in life in Strubellia (Brenzinger et al. 2011b) and wholly missing in Acochlidium (Haase and Wawra 1996). The small size of the bursa in Wallacellia may imply that it is either less functional, or becomes reduced during life. This variability of bursa sizes may be connected to copulatory behavior of freshwater Acochlidiidae and may imply alternative pathways of sperm transfer within the body. The branched shape of the ampulla of Acochlidium, sometimes even with a shortcut to the digestive gland (with unusual functional implications), is found only in that genus (Haase and Wawra 1996) and appears to be derived. Copulation was never directly observed in Acochlidiidae, their sister group Pseudunelidae, or any other of the hedylopsacean and often larger-bodied Acochlidimorpha with complex copulatory organs (Fig. 10). Acochlidium, having a complex copulatory organ reminiscent of Wallacellia siputbiru $\mathrm{n}$. gen. n. sp. but lacking both a receptacle and a bursa, is believed to inject spermatozoa hypodermically into a partner's hemocoel (Haase and Wawra 1996), a strategy found also in some other heterobranch slugs (Rivest 1984; Schmitt et al. 2007; Jörger et al. 2009; Brenzinger et al. 2011c; Lange et al. 2013). The presence of allosperm receptacles in Wallacellia siputbiru n. gen. n. sp. may thus indicate that normal copulation takes place, albeit involving a complicated and armed copulatory organ.

The anterior body cavity of the acochlidians related to Acochlidiidae (Acochlidioidea $=$ Hedylopsacea) contains a penial sheath with copulatory organ that are connected to the posterior part of the reproductive tract by a closed or open vas deferens (Schrödl and Neusser 2010; Neusser et al. 2016).

Many of these complex organs have been studied using 3D reconstruction and histology by previous authors. Judging from histology in the present material, the organ is presumably everted or protruded largely by hemolymph pressure and retracted back into the penial sheath by the retractor muscle. In Aiteng, Bathyhedyle, and Helicohedyle Drainas et al. 2018, the copulatory organ consists of the unarmed penis with associated prostate (Neusser et al. 2011a, 2016; Drainas et al. 2018). In Tantulum, the penis is also unarmed but bears a basal accessory lobe (Neusser and Schrödl 2007). In Hedylopsidae, Pseudunelidae, and Acochlidiidae, the penis is armed with a cuticular thorn or stylet, and there is a second, armed "basal finger" with associated paraprostate that may be homologous to the basal lobe in Tantulum (e.g., Neusser et al. 2011 b, this study). In the interstitial species, Hedylopsis ballantinei, prostate and paraprostate both open through the penial stylet (Kohnert et al. 2011). In all other species, the basal finger stylet is separate and presumably functions as a hypodermic needle injection paraprostatic fluid into the partner's body (Schrödl and Neusser 2010). The basal finger stylet was recorded as 30-300 $\mu \mathrm{m}$ long in Pseudunela species 
(varying between 30 and $200 \mu \mathrm{m}$ already in one interstitial species; Neusser et al. 2011b), 500-1000 $\mu \mathrm{m}$ in Strubellia (Brenzinger et al. 2011b), and roughly 50-100 $\mu \mathrm{m}$ in Acochlidium fijiensis (Haase and Wawra 1996). The 200- $\mu \mathrm{m}$-long basal finger stylet of Wallacellia siputbiru $\mathrm{n}$. gen. $\mathrm{n}$ sp. lies in the middle of these ranges (Table 1). In any case, these stylets appear long enough to penetrate the glandular epidermis of these acochlidians' bodies to reach a partner's hemocoel. The basal finger was interpreted to play a role in sperm competition or as an additional stimulatory organ similar to the dart apparatus found in some heterobranch land snails (Panpulmonata: Stylommatophora) (Haase and Wawra 1996).

The penis itself varies in general shape and morphology of the cuticular armament. The penial cuticle is also a hypodermic needle in Hedylopsis and Pseudunela species (Wawra 1989; Schrödl and Neusser 2010; Neusser et al. 2009, 2011b) and a flat hook in Strubellia (Brenzinger et al. 2011b). In Wallacellia siputbiru n. gen. n sp. and Acochlidium species (including the questionable Palliohedyle), the penial stylet is whip-like and very long and can be retracted into the penis (see below). However, stylet and hook in these species may not be homologs, since Wallacellia siputbiru $\mathrm{n}$. gen. $\mathrm{n} \mathrm{sp}$. has both structures at once: a retractable penial stylet and a terminal cuticle besides the penial opening. The latter cuticle bears minute comb-like spinelets (see results) and, according to its position and shape, may be homologous to the aforementioned thorn of Strubellia species lacking spinelets. Haase and Wawra (1996) also indicate a spine-like structure in the same position in Acochlidium but did not provide further detail about its morphology (Figs. 7 and 8); nevertheless, it does not appear to be comb-like there. So far, the comb-like aspect of the penial cuticle appears to be an autapomorphic character for Wallacellia siputbiru $\mathrm{n}$. gen. $\mathrm{n}$ sp. The cuticle likely plays a role in anchoring the penis in position during copulation. The associated gutter and intrapenial gland, also reported for Strubellia and A. fijiensis (Brenzinger et al. 2011b; Haase and Wawra 1996), may play an additional yet still unknown role in copulation.

The penial stylet presumably plays the role of transferring sperm into the earlier discussed allosperm receptacles of the partner. Observations in Acochlidium show it to protrude far from the penis ("ductus ejaculatorius" in Haase and Wawra 1996), and this likely also happens in Wallacellia siputbiru $\mathrm{n}$. gen. $\mathrm{n}$ sp. There, eversion may be achieved by contraction of the bulb underlying the penis, here termed "basal muscular bulb." This organ was so far only described in Wallacellia siputbiru n. gen. $\mathrm{n}$ sp.. It does not, however, resemble a typical muscle in histology and may even be glandular or of connective tissue, requiring future ultrastructural study to correctly interpret the function of this underlying bulb. Other acochlidiids should be critically examined for the presence of this bulb but so far published data did not mention it (Haase and Wawra 1996). The penial stylet was recorded as 70-600- $\mu \mathrm{m}$ long in 1-9-mm Pseudunela species (the longest one being coiled and the shortest one occurring in the largest species; Neusser et al. 2011b: Tables 3 and 6). It is at least $500-\mu \mathrm{m}$ long but possibly substantially longer in largerbodied Acochlidium fijiensis (Haase and Wawra 1996); it is missing in Strubellia (Brenzinger et al. 2011b). The 1600- $\mu \mathrm{m}$ long penial stylet of Wallacellia siputbiru n. gen. $\mathrm{n}$ sp. is possibly longer than in other species (Table 1) and would be long enough to reach both the bursa copulatrix ( $600 \mu \mathrm{m}$ away from the genital opening) or even the receptaculum seminis (about $1-1.2 \mathrm{~mm}$ away via the gonoduct). We could not find any evidence of hypodermic injection of spermatozoa in Wallacellia siputbiru $\mathrm{n}$. gen. $\mathrm{n}$ sp., such as presence of sperm cells in the hemocoel or inside non-reproductive organs that was reported for Acochlidium (Haase and Wawra 1996). We therefore assume that sperm transfer is into the reproductive tract. Given the apparent flexibility of the penial stylet in Wallacellia siputbiru $\mathrm{n}$. gen. $\mathrm{n}$ sp., this either indicates a rather variable place of sperm deposition, or it requires strong coupling of partners.

Coupling is presumably mainly acquired by the third armed structure in the copulatory organ that was previously termed "glans penis" (Haase and Wawra 1996) or, together with the basal finger and penis, "rapto-penis" (Schrödl and Neusser 2010). We call this structure "grappling organ" here because it is structurally independent of the penis (with ejaculatory duct) and not involved in sperm transfer but a secondary coupling device. Large coupling devices with various terminologies are known for many heterobranchs and are particularly complicated in other Panpulmonata (Glacidorbidae: Ponder 1986; Amphibolidae: Golding et al. 2008; Stylommatophora: Koene and Schulenburg 2005). As discussed for Acochlidium, notably A. fijiensis (Haase and Wawra 1996; Schrödl and Neusser 2010)), the partially invertible bulbous tip of the grappling organ in Wallacellia siputbiru $\mathrm{n}$. gen. $\mathrm{n}$ sp. with its double row of large thorns, might function like a mitten that clamps to a partner's body upon slight contraction. We suggest that the patch of smaller spines on the opposite side of the organ may also anchor in the partner's body, or alternatively in the animal's own epidermis leading to further stabilization of the coupled partners. The reconstructed specimen of Wallacellia siputbiru $\mathrm{n}$. gen. $\mathrm{n}$ sp. has more thorns $(14+15)$ and spines $(24)$ than Acochlidium species that were described to have only $8-9$ thorns per row, and 6-8 spines or no spines at all (Table 1; Bücking 1933, Bayer and Fehlmann 1960, Wawra 1979, Haase and Wawra 1996). Haase and Wawra (1996) described a spiral arrangement of thorns and spines in A. fijiensis that disagrees with the species' original description (Haynes and Kenchington 1991), and some species were differentiated based on the arrangement of thorns and spines (Wawra 1979, 1980). A robust molecular phylogenetic framework is necessary to 
properly understand variation and distribution of these presumably species-specific differences.

Thorns, stylets, and spines are termed cuticular structures in this article and throughout the literature. We would like to stress, however, that the cuticular structures of the copulatory organ have a different histology (dark blue stain) than the unequivocal cuticle of the pharynx (cuticle and radula stains light blue). As already remarked by previous authors (Haase and Wawra 1996; Brenzinger et al. 2011b), at least the spines and thorns are covered by a thin layer of the epidermis (contrary to "true" cuticle) and muscle cells grow into them. Thus, the "cuticle" of the copulatory organ may rather be part of the basally secreted extracellular matrix and not the apically secreted cuticle (Schmidt-Rhaesa 2007b), but this requires further ultrastructural study. We would expect that all tubes of the highly complex copulatory organ (ejaculatory duct including stylet, paraprostatic duct including stylet) evolved by original invagination of an ancestrally epidermal groove into the hemocoel, forming closed epithelial ducts.

\section{Apomorphies and evolution of Acochlidiidae}

Our comparative anatomical study in the context of a previous molecular phylogenetic framework found Wallacellia siputbiru n. gen. n. sp. to display a mix of plesiomorphic and derived characters in accordance with an intermediate phylogenetic position within Acochlidiidae (Table 1, Fig. 11): the new genus is a typical acochlidiid according to its relatively large size, freshwater habitat, presence of coloration, and enlarged excretory and circulatory organs (synapomorphies of the family). The new genus resembles Strubellia in all aspects except the particular greenish color and pigmentation, the reproductive tract, and the slightly flattened visceral sac. Its reproductive tract resembles Acochlidium and, where known, Palliohedyle except for the differences in cuticular armament (presence of synapomorphic penial "comb" instead of smooth thorn, higher number of grappling organ thorns and spines, and possibly longer penial stylet). The presence and extent of the head pigmentation and the basal bulb underlying the penis require further comparison to Acochlidium/Palliohedyle, and the presence of a persistently enlarged right rhinophore needs to be examined in further specimens of Wallacellia. The variable presence of allosperm receptacles (bursa and receptaculum) again suggests that the exact way of sperm transfer may be variable within the family. The presence of both a long yet retracted penial stylet and also an apical cuticle on the penis makes it unclear if the apical penial stylet of outgroup Pseudunelidae is homologous to the penial thorn, the penial stylet, or both.

Wallacellia siputbiru $\mathrm{n}$. gen. $\mathrm{n} \mathrm{sp}$. shows that in freshwater acochlidiids, the copulatory organ with additional grappling organ evolved before the flattened habitus with multiplied visceral structures that are typical for Acochlidium and presumably Palliohedyle (ampulla/renopericardioducts/dorsal vessels/gonad and digestive gland lobes). Therefore, we now know that sexual selection preceded ecological selection in the invasion of freshwater habitats by acochlidiids.

Acknowledgments We thank Jürgen Kriwet (Vienna), Thomas von Rintelen (ZMB), Ristiyanti M. Marwoto, and Daisy Wowor (MZB) for their help during fieldwork on Ambon which was made possible thanks to permits by RISTEK. Tobias Lehmann (ZSM) is thanked for embedding the sectioned specimen. Ditta Amran Balke and Stevanus Rio Tedjakumala (both Munich) are thanked for clarification of Bahasa Indonesia. Ristiyanti M. Marwoto (MZB) and Thomas von Rintelen (ZMB) are also thanked for their help in curating the voucher specimens. The Universität Bayern is thanked for providing funding for the largest part of this study; the Deutsche Forschungsgemeinschaft for support during finalization of the manuscript. Two anonymous reviewers are thanked for their careful reading of the manuscript and their constructive comments.

Data availability Vouchers are deposited at the Museum Zoologi Bogor, Bogor, Indonesia (MZB), and the Museum für Naturkunde, Berlin, Germany (ZMB).

Authors' contributions Material was collected by Matthias Glaubrecht in 2008 in Ambon. Morphological analyses were performed by Timea Neusser and Katharina Jörger (scanning electron microscopy) and Bastian Brenzinger (sectioning and 3D reconstruction). The first draft was prepared by Bastian Brenzinger and Timea Neusser. Phylogenetic background information was provided by Katharina Jörger. Funding was acquired by Michael Schrödl (DFG Schr MS667/4,9,13 to MS, BB), Bastian Brenzinger (Universität Bayern, DFG BR5727/1-1), and Matthias Glaubrecht (DFG GL 2973/7-3). All authors read and contributed to the draft of this manuscript and approved the final manuscript.

Funding Universität Bayern provided a $\mathrm{PhD}$ grant to $\mathrm{BB}$. The Deutsche Forschungsgemeinschaft DFG provided funding to BB (BR5727/1-1), MS (MS667/4,9,13), and MG (GL 297/7-3). Open Access funding was enabled and organized by Projekt DEAL.

\section{Compliance with ethical standards}

\section{Conflicts of interest None.}

Ethics approval None required.

Consent to participate None required.

Consent for publication The material was collected under RISTEK permit No. 2530/FRP/SM/X/2008 to Thomas von Rintelen, ZMB (see "Acknowledgments").

Open Access This article is licensed under a Creative Commons Attribution 4.0 International License, which permits use, sharing, adaptation, distribution and reproduction in any medium or format, as long as you give appropriate credit to the original author(s) and the source, provide a link to the Creative Commons licence, and indicate if changes were made. The images or other third party material in this article are included in the article's Creative Commons licence, unless indicated otherwise in a credit line to the material. If material is not included in the article's Creative Commons licence and your intended use is not permitted by statutory regulation or exceeds the permitted use, you will need to obtain permission directly from the copyright holder. To view a copy of this licence, visit http://creativecommons.org/licenses/by/4.0/. 


\section{References}

Abdou, A., Keith, P., \& Galzin, R. (2015). Freshwater neritids (Mollusca: Gastropoda) of tropical islands: Amphidromy as a life cycle, a review. Revue d'Écologie (Terre et vie), 70, 387-395.

Bayer, F. M., \& Fehlmann, H. A. (1960). The discovery of a freshwater opisthobranchiate mollusk, Acochlidium amboinense Strubell, in the Palau Islands. Proceedings of the Biological Society of Washington, 73, 183-194.

Beeman, R. D. (1977). Gastropoda: Opisthobranchia. In A. C. Giese \& J. S. Pearse (Eds.), Reproduction of marine invertebrates (Vol. 4, pp. 115-179). New York: Academic Press.

Bergh, R. (1895). Die Hedyliden, eine Familie der kladohepatischen Nudibranchien. Verhandlungen der $k . k$. zoologisch-botanischen Gesellschaft in Wien, 45, 1-12.

Bouchet, P., Rocroi, J. P., Hausdorf, B., Kaim, A., Kano, Y., Nützel, A., Parkhaev, P., Schrödl, M., \& Strong, E. E. (2017). Revised classification, nomenclator and typification of gastropod and monoplacophoran families. Malacologia, 61(1-2), 1-526.

Brenzinger, B., Neusser, T. P., Glaubrecht, M., Haszprunar, G., \& Schrödl, M. (2011a). Redescription and three-dimensional reconstruction of the limnic acochlidian gastropod Strubellia paradoxa (Strubell, 1892) (Gastropoda: Euthyneura) from Ambon, Indonesia. Journal of Natural History, 45(3-4), 183-209.

Brenzinger, B., Neusser, T. P., Jörger, K. M., \& Schrödl, M. (2011b). Integrating 3D-microanatomy and molecules: Natural history of the Pacific acochlidian freshwater slug Strubellia Odhner, 1937, with description of a new species. Journal of Molluscan Studies, 77, 351374

Brenzinger, B., Wilson, N. G., \& Schrödl, M. (2011c). 3D microanatomy of a gastropod 'worm', Rhodope rousei n. sp. (Heterobranchia) from southern Australia. Journal of Molluscan Studies, 77, 375-387.

Bücking, G. (1933). Hedyle amboinensis (Strubell). Zoologische Jahrbücher der Abteilung für Systematik, 64, 549-582.

Davis, A. R., \& Ponder, W. (2019). Biogeographic conundrum: Why so few stream nerite species (Gastropoda: Neritidae) in Australia? Freshwater Biology, 64(11), 2084-2088.

Dayrat, B., \& Tillier, S. (2002). Evolutionary relationships of euthyneuran gastropods (Mollusca): A cladistic re-evaluation of morphological characters. Zoological Journal of the Linnean Society, 135, 403-470.

Drainas, K., Carlson, C. H., Jörger, K. M., Schrödl, M., \& Neusser, T. P. (2018). The first helicoid sea slug: 3D microanatomy of Helicohedyle dikiki n. gen., n. sp.(Panpulmonata: Acochlidiida) from Guam. Journal of Molluscan Studies, 84(1), 1-11 [online version published 2017].

Glaubrecht, M. (1996). Evolutionsökologie und Systematik am Beispiel von Süß-und Brackwasserschnecken (Mollusca: Caenogastropoda: Cerithioidea): Ontogenese-Strategien, paläontologische Befunde und historische Zoogeographie. Leiden: Backhuys Publishers.

Glaubrecht, M. (2010). Evolutionssystematik limnischer Gastropoden. Habilitationsschrift zur Erlangung der Lehrbefähigung für das Fach Zoologie. Berlin: Humboldt-Universität Berlin.

Glaubrecht, M. (2011). Towards solving Darwin's “mystery": Speciation and radiation in lacustrine and riverine freshwater gastropods. American Malacological Bulletin, 29(1/2), 187-216.

Glaubrecht, M., \& Neiber, M. (2019). Chapter 12: Thiaridae Gill, 1872 (1823). In C. Lydeard \& K. S. Cummings (Eds.), Freshwater mollusks of the world: a distribution atlas (pp. 86-89). Baltimore: JHU Press.

Golding, R. E., Byrne, M., \& Ponder, W. F. (2008). Novel copulatory structures and reproductive functions in Amphiboloidea (Gastropoda, Heterobranchia, Pulmonata). Invertebrate Biology, $127(2), 168-180$
Haase, M., \& Wawra, E. (1996). The genital system of Acochlidium fijiense (Opisthobranchia: Acochlidioidea) and its inferred function. Malacologia, 38, 143-151.

Haszprunar, G. (1985). The Heterobranchia - a new concept of the phylogeny of the higher Gastropoda. Zeitschrift für zoologische Sytematik und Evolutionsforschung, 23, 15-37.

Haszprunar, G., \& Huber, G. (1990). On the central nervous system of Smeagolidae and Rhodopidae, two families questionably allied with the Gymnomorpha (Gastropoda: Euthyneura). Journal of Zoology (London), 220, 185-199.

Haynes, A. (1988). Notes on the stream neritids (Gastropoda; Prosobranchia) of Oceania. Micronesica, 21, 93-102.

Haynes, A. (2000). The distribution of freshwater gastropods on four Vanuatu islands: Espiritu Santo, Pentecost, Éfate and Tanna (South Pacific). Annals of Limnology, 36, 101-111.

Haynes, A., \& Kenchington, W. (1991). Acochlidium fijiensis sp. nov. (Gastropoda: Opisthobranchia: Acochlidiacea) from Fiji. The Veliger, 34, 166-171.

Jörger, K. M., Neusser, T. P., Haszprunar, G., \& Schrödl, M. (2008). Undersized and underestimated: 3D visualization of the Mediterranean interstitial acochlidian gastropod Pontohedyle milaschewitchii (Kowalevsky, 1901). Organisms, Diversity and Evolution, 8(3), 194-214.

Jörger, K. M., Heß, M., Neusser, T. P., \& Schrödl, M. (2009). Sex in the beach: Spermatophores, dermal insemination and 3D sperm ultrastructure of the aphallic mesopsammic Pontohedyle milaschewitchii (Acochlidia, Opisthobranchia, Gastropoda). Marine Biology, 156(6), 1159-1170.

Jörger, K. M., Stöger, I., Kano, Y., Fukuda, H., Knebelsberger, T., \& Schrödl, M. (2010). On the origin of Acochlidia and other enigmatic euthyneuran gastropods, with implications for the systematics of Heterobranchia. BMC Evolutionary Biology, 10, 323.

Jörger, K. M., Neusser, T. P., Brenzinger, B., \& Schrödl, M. (2014a). Exploring the diversity of mesopsammic gastropods: How to collect, identify, and delimitate small and elusive sea slugs? American Malacological Bulletin, 32(2), 290-307.

Jörger, K.M., Brenzinger, B., Neusser, T.P., Martynov, A.V., Wilson, N.G. \& Schrödl, M. (2014b). Panpulmonate habitat transitions: Tracing the evolution of Acochlidia (Heterobranchia, Gastropoda). bioRxiv, 1-72. https://doi.org/10.1101/010322.

Jörger, K. M., Neusser, T. P., Brenzinger, B., \& Schrödl, M. (2020). Chapter 15. Gastropoda. In A. Schmidt-Rhaesa (Ed.), Guide to the identification of marine meiofauna (pp. 289-307). Pfeil Verlag: Munich.

Kano, Y. (2009). Hitchhiking behaviour in the obligatory upstream migration of amphidromous snails. Biology Letters, 5(4), 465-468.

Kano, Y., \& Fukumori, H. (2010). Predation on hardest molluscan eggs by confamilial snails (Neritidae) and its potential significance in egg-laying site selection. Journal of Molluscan Studies, 76(4), $360-366$

Kano, Y., \& Fukumori, H. (2019). Chapter 3: Neritidae Rafinesque, 1815. In C. Lydeard \& K. S. Cummings (Eds.), Freshwater mollusks of the world: a distribution atlas (pp. 31-36). Baltimore: JHU Press.

Kano, Y., Fukumori, H., Brenzinger, B., \& Warén, A. (2013). Driftwood as a vector for the oceanic dispersal of estuarine gastropods (Neritidae) and an evolutionary pathway to the sunken-wood community. Journal of Molluscan Studies, 79(4), 378-382.

Kano, Y., Neusser, T. P., Fukumori, H., Jörger, K. M., \& Schrödl, M. (2015). Sea-slug invasion of the land. Biological Journal of the Linnean Society, 116(2), 253-259.

Koene, J. M., \& Schulenburg, H. (2005). Shooting darts: Co-evolution and counter-adaptation in hermaphroditic snails. BMC Evolutionary Biology, 5(1), 25.

Köhler, F., \& Glaubrecht, M. (2010). Uncovering an overlooked radiation: Molecular phylogeny and biogeography of Madagascar's 
endemic river snails (Caenogastropoda: Pachychilidae: Madagasikara gen. nov.). Biological Journal of the Linnean Society, 99(4), 867-894.

Kohnert, P., Neusser, T. P., Jörger, K. M., \& Schrödl, M. (2011). Time for sex change! 3D-reconstruction of the copulatory system of the "aphallic" Hedylopsis ballantinei (Gastropoda, Acochlidia). Thalassas, 27(2), 113-119.

Küthe, P. (1935). Organisation und systematische Stellung des Acochlidium paradoxum Strubell. Zoologische Jahrbücher der Abteilung für Systematik, 66, 513-540.

Lange, R., Reinhardt, K., Michiels, N. K., \& Anthes, N. (2013). Functions, diversity, and evolution of traumatic mating. Biological Reviews, 88(3), 585-601.

Lydeard, C., \& Cummings, K. S. (2019). Freshwater mollusks of the world: A distribution atlas. Baltimore: JHU Press.

McDowall, R. M. (2007). On amphidromy, a distinct form of diadromy in aquatic organisms. Fish and Fisheries, 8, 1-13.

Neusser, T. P., \& Schrödl, M. (2007). Tantulum elegans reloaded: A computer-based 3D visualization of the anatomy of a Caribbean freshwater acochlidian gastropod. Invertebrate Biology, 126, 18-39.

Neusser, T. P., \& Schrödl, M. (2009). Between Vanuatu tides: 3D anatomical reconstruction of a new brackish water acochlidian gastropod from Espiritu Santo. Zoosystema, 31(3), 453-469.

Neusser, T. P., \& Schrödl, M. (2019). Chapter 26: Tantulidae Rankin, 1979, and Acochlidiidae Küthe, 1935. In C. Lydeard \& K. S. Cummings (Eds.), Freshwater mollusks of the world: a distribution atlas (pp. 145-149). Baltimore: JHU Press.

Neusser, T. P., Jörger, K. M., \& Schrödl, M. (2007). Exploring cerebral features in Acochlidia (Gastropoda: Opisthobranchia). Bonner zoologische Beiträge, 55, 301-310.

Neusser, T. P., Heß, M., \& Schrödl, M. (2009). Tiny but complex interactive $3 \mathrm{D}$ visualization of the interstitial acochlidian gastropod Pseudunela cornuta (Challis, 1970). Frontiers in Zoology, 6(1), 1.

Neusser, T. P., Fukuda, H., Jörger, K. M., Kano, Y., \& Schrödl, M. (2011a). Sacoglossa or Acochlidia? 3D-reconstruction, molecular phylogeny and evolution of Aitengidae (Gastropoda, Heterobranchia). Journal of Molluscan Studies, 77, 332-350.

Neusser, T. P., Jörger, K. M., \& Schrödl, M. (2011b). Cryptic speciation in tropic sands - Interactive 3D anatomy, molecular phylogeny and evolution of meiofaunal Pseudunelidae (Gastropoda, Acochlidia). PLoS One, 6(8), e23313.

Neusser, T. P., Jörger, K. M., Lodde-Bensch, E., Strong, E. E., \& Schrödl, M. (2016). The unique deep sea-Land connection: Interactive 3D visualization and molecular phylogeny of Bathyhedyle boucheti $\mathrm{n}$. sp. (Bathyhedylidae n. fam.) - The first panpulmonate slug from bathyal zones. PeerJ, 4, e2738.

Neusser, T. P., Hanke, F., Haszprunar, G., \& Jörger, K. M. (2018). 'Dorsal vessels'? 3D-reconstruction and ultrastructure of the renopericardial system of Elysia viridis (Montagu, 1804) (Gastropoda: Sacoglossa), with a discussion of function and homology. Journal of Molluscan Studies, 85(1), 79-91.

Ponder, W. F. (1986). Glacidorbidae (Glacidorbacea: Basommatophora), a new family and superfamily of operculate freshwater gastropods. Zoological Journal of the Linnean Society, 87, 53-83.

Rankin, J. J. (1979). A freshwater shell-less mollusc from the Caribbean: Structures, biotics and contribution to a new understanding of the Acochlidioidea. Royal Ontario Museum Life Sciences Contributions, 116, 1-123.

Richardson, K. C., Jarett, L., \& Finke, E. H. (1960). Embedding in epoxy resins for ultrathin sectioning in electron microscopy. Stain Technology, 35, 313-323.

Rivest, B. R. (1984). Copulation by hypodermic injection in the nudibranchs Palio zosterae and P. dubia (Gastropoda, Opisthobranchia). The Biological Bulletin, 167(3), 543-554.
Ruppert, R. D., Fox, R. S., \& Barnes, E. E. (2003). Invertebrate zoology. A functional evolutionary approach (7th edn.). Grove: Brooks/Cole Publishing Co..

Ruthensteiner, B. (2008). Soft part 3D visualization by serial sectioning and computer reconstruction. Zoosymposia, 1(1), 63-100.

Schmidt-Rhaesa, A. (2007a). Chapter 9. Excretory systems. In A. Schmidt-Rhaesa (Ed.), The evolution of organ systems (pp. 169190). New York: Oxford University Press.

Schmidt-Rhaesa, A. (2007b). Chapter 4. Epidermis. In A. SchmidtRhaesa (Ed.), The evolution of organ systems (pp. 54-73). New York: Oxford University Press.

Schmitt, V., Anthes, N., \& Michiels, N. K. (2007). Mating behaviour in the sea slug Elysia timida (Opisthobranchia, Sacoglossa): Hypodermic injection, sperm transfer and balanced reciprocity. Frontiers in Zoology, 4(1), 17.

Schrödl, M., \& Neusser, T. P. (2010). Towards a phylogeny and evolution of Acochlidia. Zoological Journal of the Linnean Society, 158, 124-154.

Schrödl, M., \& Wägele, M. (2001). Anatomy and histology of Corambe lucea Marcus, 1959 (Gastropoda, Nudibranchia, Doridoidea), with a discussion of the systematic position of Corambidae. Organisms Diversity \& Evolution, 1(1), 3-16.

Strong, E. E., Gargominy, O., Ponder, W. F., \& Bouchet, P. (2008). Global diversity of gastropods (Gastropoda; Mollusca) in freshwater. Hydrobiologia, 595, 149-166.

Strubell, A. (1892). No title. Sitzung der naturwissenschaftlichen Sektion vom 13. Juni 1892. Verhandlungen des naturhistorischen Vereins der preussischen Rheinlande, Bonn, 56-62.

Turner, A. M., Turner, R. R., \& Ray, S. R. (2007). Competition and intraguild egg predation among freshwater snails: Re-examining the mechanism of interspecific interactions. Oikos, 116(11), 18951903

van Mol, J. J. (1967). Étude morphologique et phylogénétique du ganglion cérébroide des gastéropodes pulmonés (Mollusques). Mémoires de l'Académie Royale Belgique Sciences, 2(37(5)), 1-168.

von Rintelen, T., \& Glaubrecht, M. (2005). Anatomy of an adaptive radiation: A unique reproductive strategy in the endemic freshwater gastropod Tylomelania (Cerithioidea: Pachychilidae) on Sulawesi, Indonesia and its biogeographical implications. Biological Journal of the Linnean Society, 85(4), 513-542.

Wallace, A. R. (1869). The Malay Archipelago: The land of the OrangUtan, and the bird of paradise. A narrative of travel, with sketches of man and nature (Two volumes, 1st edn.). London: Macmillan.

Wawra, E. (1974). The rediscovery of Strubellia paradoxa (Strubell) (Gastropoda: Euthyneura: Acochlidiacea) on the Solomon Islands. The Veliger, 17, 8-10.

Wawra, E. (1979). Acochlidium sutteri nov. spec. (Gastropoda, Opisthobranchia, Acochlidiacea) von Sumba, Indonesien. Annalen des Naturhistorischen Museums Wien, 82, 595-604.

Wawra, E. (1980). Acochlidium bayerfehlmanni spec. Nov., (Gastropoda: Opisthobranchia: Acochlidiacea) from Palau Islands. The Veliger, $22,215-220$

Wawra, E. (1987). Zur Anatomie einiger Acochlidia (Gastropoda, Opisthobranchia) mit einer vorläufigen Revision des Systems und einem Anhang über Platyhedylidae (Opisthobranchia, Ascoglossa). Dissertation Nr. 17335. Vienna: Universität Vienna.

Wawra, E. (1988). Strubellia paradoxa (Strubell 1892) (Gastropoda: Opisthobranchia) von den Salomon-Inseln. Zoologischer Anzeiger, 220, 163-172.

Wawra, E. (1989). Zur Kenntnis der interstitiellen Opisthobranchierart Hedylopsis spiculifera (Kowalewsky) (Mollusca, Gastropoda). Zoologica Scripta, 18, 397-403.

Publisher's note Springer Nature remains neutral with regard to jurisdictional claims in published maps and institutional affiliations. 